North, A. C. and Hargreaves, D. J. (2007). Lifestyle correlates of musical preference: 1. Relationships, living arrangements, beliefs, and crime. Psychology of Music, 35, 58-87.

\title{
Lifestyle Correlates of Musical Preference: \\ 1. Relationships, Living Arrangements, Beliefs, and Crime
}

Adrian C. North and David J. Hargreaves*

School of Psychology, University of Leicester, University Road, Leicester LE1 7RH, United Kingdom

(Tel: +44 116252 2175; Fax: +44 116252 2067; Email: acn5@le.ac.uk)

*Faculty of Education and Language Studies, Briggs Building, The Open University, Walton Hall, Milton Keynes MK7 6AA, United Kingdom

Running Head: Lifestyle correlates of musical preference 


\begin{abstract}
Several studies indicate that musical preferences provide a means of discriminating between social groups, and suggest indirectly that musical preferences should correlate with a variety of different lifestyle choices. In this study, 2532 participants responded to a questionnaire asking them to state their musical preference and also to provide data on various aspects of their lifestyle (namely interpersonal relationships, living arrangements, moral and political beliefs, and criminal behaviour). Numerous associations existed between musical preference and these aspects of participants' lifestyle. The nature of these associations was generally consistent with previous research concerning a putative liberal-conservative divide between differing groups of fans. It is concluded that participants' musical preferences provided a meaningful way of distinguishing different lifestyle choices.
\end{abstract}




\section{Lifestyle Correlates of Musical Preference}

\section{Relationships, Living Arrangements, Beliefs, and Crime}

Abundant anecdotal evidence testifies that stereotypes exist concerning the fans of various musical styles. North and Hargreaves (1999) provided some empirical evidence for the existence of such stereotypes concerning fans of chart pop music, alternative pop music, and classical music in a sample of undergraduates and 9-10 year old children. A second study indicated that being a fan of either chart pop or rap had implications for participants' reactions to another hypothetical person who was also a fan of one of these two musical styles. Specifically, there was a tendency to provide positive evaluations of a hypothetical person who shared the participant's musical preference, and to provide negative evaluations of a hypothetical person who did not share the participant's musical preference.

Effects such as these have been explained in terms of social identity theory, which argues that such discriminations arise because they allow participants to make their group membership salient and to derive positive self-esteem from this (see e.g. Tarrant, North, and Hargreaves, 2002). This, and a few other laboratory studies (see review by Tarrant, North, and Hargreaves, 2002) indicate that musical preference is meaningful in terms of group dynamic processes. However, these studies are unable to show how the function of music as a means of discriminating social groups might manifest itself outside the laboratory, and this function deserves further investigation.

The present paper is the first of a series of three concerning how fans of different types of music might also have different lifestyles. The second and third of these 
papers (North and Hargreaves, 2005a; b) concern differences in lifestyle based on membership of high / low culture taste publics and social class groups respectively. The present paper investigates the extent to which a liberal-conservative dichotomy might differentiate fans of different musical styles on issues relating to relationships, living arrangements, beliefs, and crime. It is possible that the fans of different musical styles might well be differentiated along such a dichotomy in terms of a range of factors such as their moral and political beliefs, and interpersonal relationships.

Several studies suggest that the fans of different musical styles might indeed have differing beliefs and lifestyles based on a liberal-conservative dichotomy. Specifically, numerous studies have supported the more narrowly-defined contention that fans of certain 'problem' musical styles such as dance music, rap, and heavy metal are more involved than other fans in lifestyles containing acts of delinquency and anti-authoritarian behaviour. Hansen and Hansen (1991) found that heavy metal fans were higher on questionnaire measures of 'Machiavellianism' and 'machismo', and were lower on measures of need for cognition than were non-fans: similarly, punk fans were less accepting of authority than were non-fans. Robinson, Weaver, and Zillmann (1996) found that undergraduates who scored highly on measures of psychoticism and reactive rebelliousness enjoyed rebellious videos more than did participants who scored low on these factors. Bleich, Zillmann, and Weaver (1991) assessed 16-19 year old participants' trait rebelliousness and enjoyment of three 'defiant' and three 'non-defiant' rock music videos. Highly rebellious participants did not enjoy the defiant videos more than did their less rebellious peers. However, highly rebellious participants enjoyed the non-defiant videos less than did non-rebellious participants, and the former group also consumed less non-defiant rock music. 
Dillmann-Carpentier, Knobloch, and Zillmann (2003) found that liking for defiant music was related to forms of rebelliousness. Finally, Hansen and Hansen (1990) found that experimental exposure to antisocial music videos increased participants' tolerance of antisocial behaviour (i.e. an obscene hand gesture) as compared with exposure to non-antisocial videos.

Furthermore, the apparent link between deleterious behaviour and problem music is not confined to delinquency. Other studies have suggested a link between listening to 'aggressive' music and permissive attitudes towards violence (Johnson, Adams, Ashburn, and Reed, 1995; Johnson, Jackson, and Gatto, 1995; Peterson and Pfost, 1989; Rawlings, Hodge, Sherr, and Dempsey, 1995). Similarly, three studies have shown a link between the degree of exposure to music videos and permissive / promiscuous sexual attitudes, particularly in females (Strouse and Buerkel-Rothfuss, 1987; Strouse, Buerkel-Rothfuss, and Long, 1995; and Toney and Weaver, 1994). Research also shows a relationship between exposure to music videos and acceptance of sex discrimination (e.g. Hansen, 1989; Hansen and Hansen, 1988; Strouse, Goodwin, and Roscoe, 1994). In addition to this evidence in the academic literature, numerous magazine and newspaper articles have commented on the variety of clothing and other lifestyle choices (such as the use of a particular type of illegal drug) that seem to correlate with membership of particular musical sub-cultures, arguing that pop music represents a means of indoctrinating people into a particular, and usually deleterious, lifestyle (see e.g. Nuzum, 2001).

In addition to this research, a small number of studies have indicated specifically that fans of classical music score more highly on measures of conservatism whereas fans 
of problem music are more liberal. McLeod, Detenber, and Eveland (2001) found that participants who listened to 'problem' music lyrics did not support their censorship, whereas participants with conservative attitudes were most likely to support censorship. Lynxwiler and Gay (2000) found that participants who held conservative attitudes toward sexuality and those who attended religious services disliked heavy metal and rap. Glasgow and Cartier (1985) argued that conservatives prefer simple, familiar, and 'safe' artistic objects. McCown, Keiser, Mulhearn, and Williamson (1997) found that psychoticism was related to a preference for music with ‘exaggerated bass'. Finally, Litle and Zuckerman (1986) found that sensation-seeking was associated with liking for rock music.

Therefore the existing research indicates that liking for liberal versus conservative musical styles is associated with respectively liberal versus conservative behaviours, attitudes, and personalities. Accordingly the rationale of the present research is that liking for 'liberal' musical styles such as rap, dance music, and rock might be reflected in more generally liberal beliefs and behaviours as well as higher levels of delinquency / anti-social behaviour; and that liking for 'conservative' musical styles such as classical music would be reflected in generally conservative lifestyle preferences and relatively pro-social attitudes and behaviours. For example fans of 'problem' music styles might be expected to be relatively liberal and anti-social when compared with fans of classical music on factors such as number of sexual partners, levels of homosexuality, co-habitation outside of marriage, religious beliefs, general political preferences (and opinions concerning more specific issues such as taxation and nuclear weapons), levels of criminality and particularly drug use. These issues 
were investigated through a questionnaire distributed to fans of 35 different musical styles.

\section{Method}

2532 participants (mean age $=36.59$ years, $\underline{\mathrm{SD}}=16.03$ years) were recruited from a variety of locations in a city in the East Midlands region of the United Kingdom. In an attempt to obtain a cross-section of the general public, these locations included a university campus, a city centre shopping mall, a train station, several office complexes, a gas supply company, and an employment bureau. Full details of the sample are provided in the 'General Information' section of the Results and Discussion. All participants responded to a specially-devised questionnaire subdivided into 13 sections labelled 'General information', 'Travel', 'Relationships', 'Living Arrangements', 'Money', 'Education', 'Employment', 'Health', 'Drinking and Smoking', 'Media', 'Beliefs', 'Crime', and 'Music' respectively. The present manuscript reports those findings derived from the sections concerning general information, relationships, living arrangements, beliefs, and crime: it complements North and Hargreaves (2005a) which reports those findings from the sections of the questionnaire concerning media usage, leisure time preferences, and patterns of music usage; and North and Hargreaves (2005b) which reports those findings from sections of the questionnaire concerning travel, money, education, employment, health, and drinking and smoking.

The final section of the questionnaire ('Music') included a list of 35 different musical styles (each followed by two exemplar composers / performers). Participants were 
asked to "tick one that best describes your current taste in music". Sixteen of the 35 musical styles were selected by fewer than 50 of the respondents, and were excluded from analyses: these styles were choral music $(\mathrm{N}=34), 20^{\text {th }}$ century Classical music $(\mathrm{N}=7)$, drum \& bass $(\mathrm{N}=38)$, world music $(\mathrm{N}=24)$, ambient $(\mathrm{N}=21)$, baroque $(\mathrm{N}$ $=24)$, English folk $(\mathrm{N}=19)$, new age / relaxation $(\mathrm{N}=10)$, psychedelic Rock $(\mathrm{N}=8)$, early music $(\mathrm{N}=3)$, reggae $(\mathrm{N}=43)$, Irish folk $(\mathrm{N}=40)$, punk $(\mathrm{N}=35)$, electronic $(\mathrm{N}$ = 13), funk / acid jazz $(\mathrm{N}=47)$, and heavy metal $(\mathrm{N}=43)$. The musical styles which satisfied this criteria were opera $(N=61)$, country and western $(N=73)$, jazz $(N=$ $72)$, rock $(\mathrm{N}=194)$, current chart pop $(\mathrm{N}=133), \mathrm{R} \& \mathrm{~B}(\mathrm{~N}=131)$, soul $(\mathrm{N}=105)$, classical $(\mathrm{N}=149)$, disco $(\mathrm{N}=152)$, dance / house $(\mathrm{N}=131)$, hip hop / rap $(\mathrm{N}=66)$, musicals $(\mathrm{N}=121)$, blues $(\mathrm{N}=65), 1960$ s pop $(\mathrm{N}=118)$, indie $(\mathrm{N}=128)$, adult pop / MOR $(\mathrm{N}=156)$, DJ-based music $(\mathrm{N}=65)$, other pop music styles $(\mathrm{N}=78)$, and other musical styles $(\mathrm{N}=64)$. In addition to this, a further 61 participants failed to state their preferred musical style or ticked more than one, and these participants' data were also excluded from analyses. This produced a final sample for analysis of 2062 participants. Most items on the questionnaire asked participants to select from several pre-defined response options or to provide a specific number (e.g. the number of people who live in their home). Some items required participants to give a rating on an 11-point Likert scale where 0 represented the low point and 10 represented a correspondingly high rating. Full details of the questionnaire are provided in the Results and Discussion section below.

\section{Results and Discussion}




\section{$\underline{\text { General Information }}$}

Two separate $\chi^{2}$ tests were carried out to investigate associations between participants' musical preferences and respectively their sex and ethnic background. The resulting frequencies are reported in Tables 1 and 2, which indicate a significant association between musical preference and both of these factors. With regard to ethnic origin, note that the more detailed breakdown of participants was BlackAfrican $=21$ participants, Black-Caribbean $=30$ participants, Black-Other $=23$ participants, Asian-Indian $=132$ participants, Asian-Pakistani $=24$ participants, Asian-Bangladeshi $=9$ participants, Asian-Chinese $=24$ participants, Asian-Other $=$ 39 participants, and White $=2222$ participants. With regard to age 919 participants were aged under 18 years, 371 participants were aged 18-34 years, 130 participants were aged 35-59 years, and 642 participants were aged 60+ years. A one-way ANOVA was carried out to test for any differences in age between the fans of different musical styles. The result of this was significant $(F(18,2024)=60.20$, p < .001). Tukey HSD tests indicated 9 homogenous sub-sets of means, which are presented in Table 3.

- Tables 1-3 about here -

In addition to the data presented in Tables 1 and 2, this one-way ANOVA is consistent with previous research on 'taste publics', which indicates an association between musical taste and participants' demographic characteristics. With regard to sex, for example, fans of opera, current chart pop, R\&B, disco, dance / house, musicals, and other pop music styles were predominantly female, whereas fans of 
blues were predominantly male. With regard to ethnic background, although the great majority of participants were white, a relatively high proportion of participants from an Asian background liked R\&B, dance / house, and hip hop / rap. With regard to age, it is unsurprising that fans of what are arguably currently fashionable musical styles such as hip hop / rap, DJ-based music, dance / house, R\&B, indie, and current chart pop should be of a homogenously low age compared to the remainder of the sample: it is similarly unsurprising that fans of what are arguably currently unfashionable musical styles such as classical music, 1960s pop, musicals, opera, and country and western should be of a homogenously high age compared to the remainder of the sample. It is not the case however that age is positively related to a liking for high art music: fans of 1960s pop and country and western were amongst the oldest within the present sample. Rather, it is more accurate to state that fans of high art musical styles are unlikely to be young.

\section{$\underline{\text { Relationships }}$}

Eight separate $\chi^{2}$ tests were carried out to investigate any association between participants' musical preferences and seven respective aspects of their interpersonal relationships. The first test showed a significant association with the type of family group in which participants were brought up (i.e. both parents versus other). The second test showed a significant association with whether participants were currently in a romantic relationship. The third test showed no significant association with whether participants were in a romantic relationship with a partner of the same or different sex. The fourth test showed a significant association with the number of sexual partners the participants had had during the past five years (with participants 
responding to this item by choosing from three different options). The fifth test showed a significant association with whether the participant was currently married, single, or had a deceased spouse. The sixth test showed a significant association with whether the participant had ever been divorced. The seventh test showed a significant association with whether the participant was or was not living with their romantic partner. The eighth test showed no significant association with whether the participant had or wanted to have children. The resulting frequencies are shown in Tables 4-6.

- Tables 4-6 about here -

Table 4 indicates that the majority of participants were brought up by both of their parents. However, a relatively high proportion of fans of country, $R \& B$, soul, dance / house, hip hop / rap were brought up outside two-parent families. Table 4 indicates that a relatively high proportion of fans of classical music, blues, 1960s pop, and adult pop were currently in a romantic relationship; whereas a relatively low proportion of fans of opera, current chart pop, dance / house, hip hop / rap, musicals, DJ-based music, and other music were currently in a romantic relationship. Indeed it is interesting to consider this finding in the light of the data presented in Table 5. This indicates that dance / house, hip hop / rap, and DJ-based music were the most likely participants to have had more than one sexual partners during the past 5 years. Although the data presented in Table 4 indicates that there was no significant association between the different musical styles and whether the participants were in a romantic relationship with a partner of the same or opposite sex, it is interesting that a relatively low proportion of the fans of dance / house and hip hop / rap were in a relationship with someone of the opposing sex. It is tempting to speculate that, in 
conjunction with the data on promiscuity reported in Table 5, this is contrary to the generally liberal stereotype of the fans of the latter two musical styles. Although the fans of dance / house and hip hop / rap are by no means predominantly male (see Table 1), these data suggest that the fans have a stereotypically masculine approach to sexual relationships, with low levels of (self-reported) homosexuality and a high level of (self-reported) promiscuity. In contrast, it is also worth noting that Table 5 indicates that a very high proportion of the fans of opera, country and western, classical music, musicals, and 1960s pop had been monogamous or had no sexual partners during the past 5 years.

The data in Table 5 concerning whether or not the participants were currently married is consistent with that on promiscuity. The former indicates that the most promiscuous fans (namely those of dance / house, hip hop / rap, and DJ-based music) were the least likely to be married. In contrast the least promiscuous fans (namely those of opera, country and western, classical music, musicals, and 1960s pop) were among those most likely to be married. Other fans who were relatively likely to be married were those of blues and adult pop. Fans of opera and musicals were relatively likely to be widow(er)s, consistent with their higher age (see Table 3): however given their relatively young age, fans of jazz might be interpreted as relatively likely to be widow(er)s, whereas the high mean age of country and western fans means that they are perhaps fortunate in that only $5.6 \%$ of them were widow(er)s. Age variations between the fans of the different styles might also explain some of the data presented in Table 5 concerning divorce (since older fans have had greater opportunity to be divorced). In particular, fans of current chart pop, dance / house, hip hop / rap, indie, and DJ-based music were among the youngest fans (see Table 3) and those least likely 
to have been divorced (see Table 5). However variations in divorce rates between the fans of other musical styles are much more difficult to explain simply in terms of age. For example, fans of adult pop and disco were of very similar mean ages, but $17.0 \%$ of the fans of adult pop had been divorced compared with only $10.8 \%$ of the fans of disco: fans of country and western music were the oldest in the present sample (see Table 3), but their divorce rate (of 17.1\%) was comparable with that of the fans of adult pop (17.0\%) who were almost 12 years younger on average. In a similar vein, it is perhaps unsurprising that Table 6 shows that the oldest groups of fans were among the most likely to be living with their romantic partner, although again there are some differences between different groups of fans that are difficult to explain in terms of this argument, given the similarity in their mean ages: for example, despite the similarity in their ages, $42.2 \%$ of indie fans live with their partner compared to only $25.2 \%$ of the fans of dance / house.

In addition to providing this information, participants were also asked to state the number of months for which they had lived with their romantic partner, and to provide Likert scale ratings for three further variables, namely the extent to which they preferred larger groups over one-to-one interactions; the extent to which they would like to have more friends; and the extent to which their current friends were outgoing. A separate one-way ANOVA was carried out for each of these four variables to investigate any difference between the musical preference groups. These indicated that significant differences obtained between the musical preference groups for each of the variables except the second $(\mathrm{F}(18,1035)=15.61, \mathrm{p}<.001 ; \mathrm{F}(18$, $1995)=1.44$, n.s.; $\mathrm{F}(18,2010)=2.95, \mathrm{p}<.001 ;$ and $\mathrm{F}(18,2005)=6.96, \mathrm{p}<.001$ respectively). Homogenous sub-sets of means (as indicated by Tukey HSD tests) for 
those variables giving rise to significant results are presented in Tables 6-7. The data presented in Table 6 concerning whether the participant is currently living with their romantic partner and has or wants to have children supports that concerning the number of months for which participants had lived with their romantic partner and requires no further discussion. Table 7 indicates that classical music fans were most satisfied with their existing number of friends whereas fans of hip hop / rap, R\&B, and dance / house music were the most eager to have more friends. Table 7 indicates that the latter three groups of fans, along with fans of current chart pop and DJ-based music, also had the most outgoing friends, whereas fans of musicals, classical music, opera, and country and western had the least outgoing friends.

- Table 7 about here -

This highlights a distinct pattern of results from this section of the questionnaire: at the risk of over-generalising, responses seem to fall into three loose groupings, with those from the fans of country and western, opera, musicals, 1960s pop, adult pop, classical music, and blues being the most conservative in their relationships, responses from fans of hip hop / rap, DJ-based music, and dance / house being the least conservative in their relationships (with the notable exception of their propensity towards homosexuality), and responses from the fans of other musical styles falling between those of the two other groups. Such a pattern of responses is inconsistent with the often-claimed dichotomy between classical and pop music: the present data seems to group together fans of classical music, adult pop, and 1960s pop. Similarly, this pattern of responses is inconsistent with the often-claimed and more general dichotomy between high culture and low culture: the present data seems to group 
together fans of country and western with fans of opera. Rather the groupings of fans highlighted here seem more consistent with a distinction between musical styles that promote conservative versus liberal ideologies. Note that this conservative-liberal distinction cannot be regarded as rooted within simple age differences between the fans of different musical styles (such that older fans are more conservative than younger fans): the data presented in this section provide numerous examples of how groups of fans with similar mean ages are very different in terms of their scores on other variables. For example, fans of indie were of a very similar age to fans of e.g. hip hop / rap, but tended to produce markedly different data.

\section{$\underline{\text { Living arrangements }}$}

Three separate $\chi^{2}$ tests were carried out to investigate any association between participants' musical preferences and eight respective aspects of their living arrangements. The first test showed a significant association with whether the participant owned his / her own home. The second test showed a significant association with the type of home in which the participant lived (and note that 70 participants who lived in bungalows were excluded from this analysis since they were too widely dispersed across the different musical styles). The third test showed a significant association with whether participants had spent more than half of their life in the same TV region in which they were born. The resulting frequencies are shown in Tables 8-9. In addition to providing this information, participants were also asked to state the number of people who lived in their home in addition to themselves (and could include children, elderly relatives etc.); how many of these people had a personal income in excess of $£ 1000$ per annum; and to provide a Likert scale rating of 
the extent to which they lived in an urban versus rural area. A series of three separate one-way ANOVAs showed that only the last of these three variables did not give rise to significant differences between the musical preference groups $(F(18,2022)=5.18$, $\mathrm{p}<.001 ; \mathrm{F}(18,1967)=3.28, \mathrm{p}<.001 ;$ and $\mathrm{F}(18,1992)=1.11$, n.s. respectively $)$. Homogenous sub-sets of means for those variables giving rise to significant results (as indicated by Tukey HSD tests) are presented in Table 10.

- Tables 8-10 about here -

Table 8 indicates that fans of opera, country and western, classical music, and adult pop were most likely to own their own home whereas fans of $R \& B$, dance / house, hip hop / rap, and DJ-based music were least likely to. Fans of opera, jazz, classical music, hip hop / rap, and adult pop were most likely to live in a detached home (i.e. the most expensive type of housing); whereas R\&B, hip hop / rap, and blues fans were most likely to live in a terraced house, and fans of jazz, rock, DJ-based music, other pop, and other musical styles were most likely to live in a flat. Table 9 indicates that fans of blues and country and western were least likely to still live within the same TV region (i.e. same geographical area) in which they were born. Table 10 indicates that fans of country and western and opera lived with the fewest number of other people, whereas fans of hip hop / rap lived with the greatest number of other people. Table 10 indicates that fans of jazz lived in households where the fewest number of people had an annual income in excess of $£ 1000$ per annum, whereas fans of hip hop / rap scored highest in this respect. More generally, the data presented in this section indicate numerous differences in the living arrangements of the fans of different musical styles. 


\section{$\underline{\text { Beliefs }}$}

Four separate $\chi^{2}$ tests were carried out to investigate any association between participants' musical preferences and four respective aspects of their political and moral beliefs. The first test showed a significant association with the political party for which the participant usually voted (and note that this analysis excluded 50 participants who voted for an 'Other' party since these people were too widely dispersed across the musical preference groups to allow analysis). The second test showed a significant association with whether the participant was vegetarian / vegan. The third test showed a significant association with the religion with which the participant associated him / herself most closely. The fourth test showed a significant association with whether participants who were religious worshipped as regularly as their religion said they should. The resulting frequencies are shown in Tables 11-12. Table 11 indicates that fans of country and western, opera, and jazz were most likely to vote for the most right-wing of Britain's main political parties, the Conservatives. This is consistent with the earlier assertion that these fans are more generally among the most conservative within the present sample. In contrast, fans of rock, indie, and other music styles were most likely to vote for what is at present arguably Britain's most left-wing main political party, the Liberal Democrats. Table 12 indicates that fans of soul were most likely to be vegetarian / vegan, whereas fans of disco and DJbased music were least likely to be. Table 12 indicates that fans of dance / house, indie, and DJ-based music were most likely to not be religious, whereas fans of country and western, classical music, disco, and musicals were least likely to not be religious (i.e. most likely to be religious); fans of rock, musicals, and adult pop were 
most likely to be Protestant; fans of opera and country and western were most likely to be Catholic; and fans of R\&B and hip hop / rap were most likely to follow other religions. Table 12 shows that of those participants who were religious, fans of opera, musicals, and other musical styles were most likely to worship as regularly as their religion said they ought, whereas fans of disco were least likely to worship as regularly as they ought.

- Table 11-12 about here -

Participants were asked to state whether or not they regularly recycled each of glass, paper, aluminium cans, plastic, and old clothes. A score of 1 was awarded for each of these items recycled and a total was calculated for each participant. An ANOVA was carried out to test for any difference between the musical preference groups in these total recycling scores. The result of this was significant $(F(18,2019)=2.77, p<.001)$ and homogenous sub-sets of means are provided in Table 13. These means indicate that fans of country and western, sixties pop, classical music, and opera were most likely to recycle whereas fans of DJ-based music, hip hop / rap, and R\&B were least likely to recycle, contrary again to their liberal stereotype.

- Table 13 about here -

Participants were then asked to provide ratings on Likert scales concerning 11 particular socio-political issues. A separate one-way ANOVA was carried out for each issue, with ratings indicating a significant difference between the musical preference groups on whether they believed that taxes should be raised in order to pay for 
improved public services $(\mathrm{F}(18,1957)=3.64, \mathrm{p}<.001)$; whether they believed that the Government should do more to exploit alternative energy sources $(F(18,1944)=$ $3.62, \mathrm{p}<.001)$; whether they believed that Scotland should be granted full independence from the United Kingdom should most Scots want it $(F(18,1922)=$ 1.67, $\mathrm{p}<.05)$; whether they believed that Britain should enter the Euro if the economic conditions were right $(\mathrm{F}(18,1919)=1.76, \mathrm{p}<.05)$; whether they believed that nuclear weapons reduce the risk of international conflict $(\mathrm{F}(18,1907)=3.09, \mathrm{p}<$ $.001)$; whether they believed that the Government should pay more attention to environmental issues $(\mathrm{F}(18,1918)=1.92, \mathrm{p}<.05)$; and whether they believed Britain should retain a state-funded National Health Service $(F(18,1929)=4.30, p<.001)$. Homogenous sub-sets of means for those variables giving rise to significant results (as indicated by Tukey HSD tests) are presented in Tables 14-15. One-way ANOVAs indicated no significant differences between the musical preference groups on ratings of whether they believed that the USA's foreign policy was too aggressive (F (18, $1873)=1.47$, n.s.); whether they believed that Britain should play a more active role in international relations $(\mathrm{F}(18,1915)=1.25$, n.s. $)$; whether they believed that Republicans in Northern Ireland should be favoured over Unionists $(\mathrm{F}(18,1781)=$ 1.06 , n.s.); and whether they believed children should be taught in separate classes on the basis of their academic ability $(\mathrm{F}(18,1932)=1.06$, n.s. $)$.

- Tables 14-15 about here -

Table 14 indicates that fans of opera and classical music were most in favour of raising taxation to pay for improved public services, whereas fans of $\mathrm{R} \& \mathrm{~B}$, hip hop / rap, current chart pop, and DJ-based music were least in favour of increasing taxes. 
Fans of jazz, indie, classical music, blues, and opera agreed most strongly that the Government should do more to exploit alternative energy sources, whereas fans of hip hop / rap, R\&B, and current chart pop disagreed most with this assertion. Fans of blues were most likely to agree with Scottish independence whereas fans of musicals were least likely to. Table 15 indicates that fans of indie, hip hop / rap, soul, and jazz were most likely to believe that the UK should join the Euro whereas fans of musicals, current chart pop, country and western, and adult pop were least likely to. Fans of blues, 1960s pop, country and western, and musicals were most likely to believe that nuclear weapons discourage international conflict whereas fans of other musical styles, dance / house, other pop music styles, and R\&B were least likely to. Fans of indie, country and western, 1960s pop, and rock were most likely to believe that the Government should pay more attention to environmental issues, whereas fans of other pop music styles, hip hop / rap, R\&B, DJ-based music, and dance / house were least likely to. Fans of country and western, musicals, classical music, and blues were more likely than most to believe that state-funded health care should be retained, whereas fans of hip hop / rap, dance / house, $R \& B$, and DJ-based music were least likely to believe in this.

At the risk of over-generalising, as with previous sections of the questionnaire, participants' responses to items concerning their beliefs seem to fall into three loose groupings. Again there seems to be some similarity in the responses of fans of country and western, opera, musicals, 1960s pop, adult pop, classical music, and blues; and between the responses of fans of hip hop / rap, DJ-based music, and dance / house. Furthermore there was some evidence that these two sets of fans could be distinguished in terms of their degree of conservatism. Fans of hip hop / rap, DJ-based 
music, and dance / house were less likely to be religious. Similarly, fans of country and western, opera, musicals, 1960s pop, adult pop, classical music, and blues were generally more likely to be religious, and to worship as regularly as they should. However, fans of hip hop / rap, DJ-based music, and dance / house were no more likely than most to be vegetarian or to vote for liberal political parties, and were among the least likely groups of fans to agree with liberal beliefs such as increased taxation to pay for public services, exploitation of alternative energy sources, and state-funded health care. In short, although the fans of 'problem' musical styles had some liberal beliefs their responses also indicated a rather anti-social element consistent with previous research concerning their elevated level of delinquency. In contrast fans of country and western, opera, musicals, 1960s pop, adult pop, classical music, and blues were among the most likely to agree with these pro-social beliefs.

\section{$\underline{\text { Crime }}$}

Three separate $\chi^{2}$ tests were carried out to investigate any association between participants' musical preferences and three respective aspects of their criminal behaviour. The first test showed a significant association with whether the participant had ever received a penalty for a minor motoring offence. The second test showed a significant association with whether the participant had ever been arrested. The third test showed a significant association with whether the participant had ever committed an act which, had it been detected by police, would have led to their arrest. The resulting frequencies are shown in Table 16. Participants were also asked to state whether they had ever tried each of solvents, temazepam, psilocybin, amphetamine, LSD, ecstasy, cocaine, heroin, magic mushrooms, or any other illegal drugs. 
Participants were also asked to state whether they had ever tried narium: this is a fictional drug and any participant who stated that they had tried it $(\mathrm{N}=7)$ was excluded from further analyses concerning drug usage. A score of 1 was awarded for each type of drug tried and a total was calculated for each participant. An ANOVA was carried out to test for any difference between the musical preference groups in these total drug use scores. The result of this was significant $(F(18,1929)=7.68, p<$ .001 ) and homogenous sub-sets of means are provided in Table 17. The number of fans within each musical preference group who had tried each of the different types of drugs is shown in Table 18. Finally, participants were asked to state if they had ever tried cannabis and if they had never tried any illegal drugs, with $\chi^{2}$ tests indicating a significant association between both of these and musical preference $\left(\chi^{2}(18)=\right.$ $101.01, \mathrm{p}<0.001$ and $\chi^{2}(18)=151.39, \mathrm{p}<0.001$ respectively). The resulting frequencies from these tests are shown in Table 18.

- Tables 16-18 about here -

Table 16 indicates that fans of R\&B, hip hop / rap, and DJ-based music were least likely of all the participants to drive, although this is perhaps attributable to their age (see Table 3). However, despite the fact that they were much older, fans of country and western, other musical styles, and 1960s pop were also relatively unlikely to drive. Furthermore, fans of musicals seem to stand out as having been relatively unlikely to have received a driving penalty. It is also worth noting that despite the claims of previous studies, and their delinquent stereotype, fans of 'problem' musical styles such as hip hop / rap and rock were no more likely than most to have received a driving penalty. A similar pattern of findings obtained when considering whether 
participants had been arrested. Fans of rock music were among those fans least likely to have been arrested: although fans of hip hop / rap were among those more likely to have been arrested, the relevant percentage was no greater than for fans of blues and perhaps not a great deal higher than for fans of country and western. However, fans of dance / house, hip hop / rap, indie, and DJ-based music stand out much more when considering whether they had ever committed an 'arrestable' act. The most likely explanation of these higher percentages is provided by Table 17 which indicates that fans of musicals, adult pop, rock, and classical music had tried the narrowest range of drugs whereas fans of dance / house, hip hop / rap, DJ-based music had tried the widest.

Table 18 illustrates that although fans of dance / house, hip hop / rap, DJ-based had tried the widest range of drugs, they still very much had 'drugs of choice' that they were particularly likely to try (i.e. amphetamine, LSD, and ecstacy) whereas they seemed relatively uninterested in other drugs (e.g. heroin). More simply, there is evidence that particular types of drugs are associated with particular musical subcultures. However although different groups of fans were differentially likely to have tried cannabis it is also worth noting that a considerable proportion of the fans of all the musical styles considered in the present research had tried this drug (including approximately a quarter of the fans of opera and classical music). Similarly, although $12.3 \%$ of hip hop / rap fans had tried magic mushrooms, so had $12.3 \%$ of opera fans and $12.9 \%$ of soul fans. In short, although the fans of dance / house, hip / hop / rap, and DJ-based music had tried a greater range of drugs, it would be wrong to assume that these fans are the only ones with an interest in them. 


\section{Conclusion}

The findings described above indicate numerous associations between participants' musical preferences and various aspects of their interpersonal relationships, living arrangements, beliefs, and criminal behaviour. As such they suggest that musical preference is a means of differentiating the lifestyles of particular groups of fans. There was also a considerable amount of evidence for the more specific assertion that it might be possible to differentiate groups of fans along a liberal-conservative dichotomy such that fans of 'problem' music should evidence liberal yet occasionally anti-social lifestyles and beliefs, whereas fans of classical music and other styles should evidence relatively conservative, law-abiding lifestyles. 


\section{References}

Bleich, S., Zillmann, D., and Weaver, J. B. (1991). Enjoyment and consumption of defiant rock music as a function of adolescent rebelliousness. Journal of Electronic and Broadcasting Media, 35, 351-366.

Dillmann-Carpentier, F., Knobloch, F., and Zillmann, D. (2003). Rock, rap, and rebellion: comparisons of traits predicting selective exposure to defiant music. Personality and Individual Differences, $\underline{35}$, 1643-1655.

Glasgow, M. R. and Cartier, A. M. (1985). Conservatism, sensation-seeking and music preferences. Personality and Individual Differences, $\underline{6}, 393-395$.

Hansen, C. H. (1989). Priming sex-role stereotypic event schemas with rock music videos: effects on impression favorability, trait inferences, and recall of a subsequent male-female interaction. Basic and Applied Social Psychology, 10, 371-391.

Hansen, C. H. and Hansen, R. D. (1988). How rock music videos can change what is seen when boy meets girl: priming stereotypic appraisal of social interactions. $\underline{\text { Sex }}$ $\underline{\text { Roles, }} \underline{\text { 19, }}$ 287-316.

Hansen, C. H. and Hansen, R. D. (1990). Rock music videos and antisocial behavior. Basic and Applied Social Psychology, 11, 357-369. 
Hansen, C. H. and Hansen, R. D. (1991). Constructing personality and social reality through music: individual differences among fans of punk and heavy metal music.

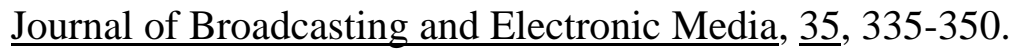

Johnson, J. D., Adams, M. S., Ashburn, L., and Reed, W. (1995). Differential gender effects of exposure to rap music on African American adolescents' acceptance of teen dating violence. $\underline{\text { Sex Roles, }}$ 33, 597-605.

Johnson, J. D., Jackson, L. A., and Gatto, L. (1995). Violent attitudes and deferred academic aspirations: deleterious effects of exposure to rap music. Basic and Applied

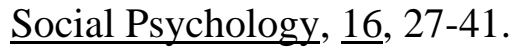

Litle, P. and Zuckerman, M. (1986). Sensation seeking and music preferences. Personality and Individual Differences, $\underline{7}$, 575-577.

Lynxwiler, J. and Gay, D. (2000).Moral boundaries and deviant music: public attitudes toward heavy metal and rap. Deviant Behavior, 21, 63-85.

McCown, W., Keiser, R., Mulhearn, S. and Williamson, D. (1997). The role of personality and gender in preference for exaggerated bass in music. Personality and Individual Differences, 23, 543-547.

McLeod, D. M., Detenber, B. H., and Eveland, W. P. (2001). Behind the third-person effect: differentiating perceptual processes for self and other. Journal of

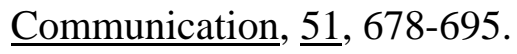


North, A. C. and Hargreaves, D. J. (1999). Music and adolescent identity. Music Education Research, 1, 75-92.

North, A. C. and Hargreaves, D. J. (2005a). Lifestyle correlates of musical preference 2. Media, leisure time, and music. Manuscript under review.

North, A. C. and Hargreaves, D. J. (2005b). Lifestyle correlates of musical preference 3. Travel, money, education, employment, and health. Manuscript under review.

Nuzum, E. (2001). Parental advisory: music censorship in America. New York: Perennial.

Peterson, D. L. and Pfost, K. S. (1989). Influence of rock videos on attitudes of violence against women. Psychological Reports, $\underline{64}, 319-322$.

Rawlings, D., Hodge, M., Sherr, D., and Dempsey, A. (1995). Toughmindedness and preference for musical excerpts, categories, and triads. Psychology of Music, $\underline{23}$, 6380.

Robinson, T. O., Weaver, J. B., and Zillmann, D. (1996). Exploring the relation between personality and the appreciation of rock music. $\underline{\text { Psychological Reports, }} \underline{78}$, 259-269. 
Strouse, J. S. and Buerkel-Rothfuss, N. L. (1987). Media exposure and the sexual attitudes and behaviors of college students. Journal of Sex Education and Therapy, $\underline{13}$, $43-51$.

Strouse, J. S., Buerkel-Rothfuss, N., and Long, E. C. J. (1995). Gender and family as moderators of the relationship between music video exposure and adolecent sexual permissiveness. Adolescence, $\underline{30}$, 505-521.

Strouse, J. S., Goodwin, M. P., and Roscoe, B. (1994). Correlates of attitudes toward sexual harassment among early adolescents. $\underline{\text { Sex Roles, }} \underline{31}, 559-577$.

Tarrant, M., North, A. C., and Hargreaves, D. J. (2002). Youth identity and music. In R. A. R. MacDonald, D. J. Hargreaves, and D. Miell (eds.), Musical identities. Oxford: Oxford University Press. Pp.134-150.

Toney, G. T. and Weaver, J. B. (1994). Effects of gender and gender role selfperceptions on affective reactions to rock music videos. Sex Roles, $\underline{30}, 567-583$. 


\begin{tabular}{|c|c|c|}
\hline & Male & Female \\
\hline Opera & $\begin{array}{c}20 \\
(32.8 \%)\end{array}$ & $\begin{array}{c}41 \\
(67.2 \%)\end{array}$ \\
\hline Country \& western & $\begin{array}{c}33 \\
(45.2 \%)\end{array}$ & $\begin{array}{c}40 \\
(54.8 \%)\end{array}$ \\
\hline Jazz & $\begin{array}{c}39 \\
(54.2 \%)\end{array}$ & $\begin{array}{c}33 \\
(45.8 \%)\end{array}$ \\
\hline Rock & $\begin{array}{c}87 \\
(44.8 \%)\end{array}$ & $\begin{array}{c}107 \\
(55.2 \%)\end{array}$ \\
\hline Current chart pop & $\begin{array}{c}22 \\
(16.7 \%)\end{array}$ & $\begin{array}{c}110 \\
(83.3 \%)\end{array}$ \\
\hline $\mathrm{R} \& \mathrm{~B}$ & $\begin{array}{c}36 \\
(27.7 \%)\end{array}$ & $\begin{array}{c}94 \\
(72.3 \%)\end{array}$ \\
\hline Soul & $\begin{array}{c}41 \\
(39.0 \%)\end{array}$ & $\begin{array}{c}64 \\
(61.0 \%)\end{array}$ \\
\hline Classical & $\begin{array}{c}68 \\
(45.6 \%) \\
\end{array}$ & $\begin{array}{c}81 \\
(54.4 \%) \\
\end{array}$ \\
\hline Disco & $\begin{array}{c}50 \\
(32.9 \%)\end{array}$ & $\begin{array}{c}102 \\
(67.1 \%)\end{array}$ \\
\hline Dance / house & $\begin{array}{c}50 \\
(38.2 \%) \\
\end{array}$ & $\begin{array}{c}81 \\
(61.8 \%) \\
\end{array}$ \\
\hline Hip hop / rap & $\begin{array}{c}29 \\
(43.9 \%)\end{array}$ & $\begin{array}{c}37 \\
(56.1 \%) \\
\end{array}$ \\
\hline Musicals & $\begin{array}{c}31 \\
(25.6 \%)\end{array}$ & $\begin{array}{c}90 \\
(74.4 \%)\end{array}$ \\
\hline Blues & $\begin{array}{c}47 \\
(72.3 \%) \\
\end{array}$ & $\begin{array}{c}18 \\
(27.7 \%) \\
\end{array}$ \\
\hline Sixties pop & $\begin{array}{c}53 \\
(44.9 \%) \\
\end{array}$ & $\begin{array}{c}65 \\
(55.1 \%) \\
\end{array}$ \\
\hline Indie & $\begin{array}{c}65 \\
(50.8 \%)\end{array}$ & $\begin{array}{c}63 \\
(49.2 \%)\end{array}$ \\
\hline Adult pop & $\begin{array}{c}60 \\
(38.5 \%)\end{array}$ & $\begin{array}{c}96 \\
(61.5 \%)\end{array}$ \\
\hline DJ based & $\begin{array}{c}32 \\
(49.2 \%)\end{array}$ & $\begin{array}{c}33 \\
(50.8 \%)\end{array}$ \\
\hline Other pop & $\begin{array}{c}16 \\
(20.5 \%) \\
\end{array}$ & $\begin{array}{c}62 \\
(79.5 \%) \\
\end{array}$ \\
\hline Other & $\begin{array}{c}27 \\
(42.2 \%)\end{array}$ & $\begin{array}{c}37 \\
(57.8 \%)\end{array}$ \\
\hline
\end{tabular}

Table $1-$ Sex by musical preference 


\begin{tabular}{|c|c|c|c|}
\hline & Black & Asian & White \\
\hline Opera & $\begin{array}{c}2 \\
(3.3 \%)\end{array}$ & $\begin{array}{c}4 \\
(6.6 \%)\end{array}$ & $\begin{array}{c}55 \\
(90.2 \%)\end{array}$ \\
\hline Country \& western & $\begin{array}{c}3 \\
(4.1 \%)\end{array}$ & $\begin{array}{c}4 \\
(5.5 \%)\end{array}$ & $\begin{array}{c}66 \\
(90.4 \%)\end{array}$ \\
\hline Jazz & $\begin{array}{c}6 \\
(8.5 \%)\end{array}$ & $\begin{array}{c}9 \\
(12.7)\end{array}$ & $\begin{array}{c}56 \\
(78.9 \%)\end{array}$ \\
\hline Rock & $\begin{array}{c}3 \\
(1.6 \%)\end{array}$ & $\begin{array}{c}7 \\
(3.6 \%)\end{array}$ & $\begin{array}{c}183 \\
(94.8 \%)\end{array}$ \\
\hline Current chart pop & $\begin{array}{c}0 \\
(.0 \%)\end{array}$ & $\begin{array}{c}12 \\
(9.1 \%)\end{array}$ & $\begin{array}{c}120 \\
(90.9 \%)\end{array}$ \\
\hline $\mathrm{R} \& \mathrm{~B}$ & $\begin{array}{c}7 \\
(5.4 \%)\end{array}$ & $\begin{array}{c}36 \\
(27.7 \%)\end{array}$ & $\begin{array}{c}87 \\
(66.9 \%)\end{array}$ \\
\hline Soul & $\begin{array}{c}9 \\
(8.6 \%)\end{array}$ & $\begin{array}{c}14 \\
(13.3 \%)\end{array}$ & $\begin{array}{c}82 \\
(78.1 \%)\end{array}$ \\
\hline Classical & $\begin{array}{c}1 \\
(.7 \%)\end{array}$ & $\begin{array}{c}8 \\
(5.4 \%)\end{array}$ & $\begin{array}{c}139 \\
(93.9 \%)\end{array}$ \\
\hline Disco & $\begin{array}{c}2 \\
(1.3 \%)\end{array}$ & $\begin{array}{c}9 \\
(5.9 \%)\end{array}$ & $\begin{array}{c}141 \\
(92.8 \%)\end{array}$ \\
\hline Dance / house & $\begin{array}{c}6 \\
(4.6 \%)\end{array}$ & $\begin{array}{c}16 \\
(12.2 \%)\end{array}$ & $\begin{array}{c}109 \\
(83.2 \%)\end{array}$ \\
\hline Hip hop/rap & $\begin{array}{c}4 \\
(6.2 \%)\end{array}$ & $\begin{array}{c}26 \\
(40.0 \%)\end{array}$ & $\begin{array}{c}35 \\
(53.8 \%)\end{array}$ \\
\hline Musicals & $\begin{array}{c}0 \\
(.0 \%)\end{array}$ & $\begin{array}{c}6 \\
(5.0 \%)\end{array}$ & $\begin{array}{c}115 \\
(95.0 \%)\end{array}$ \\
\hline Blues & $\begin{array}{c}4 \\
(6.2 \%)\end{array}$ & $\begin{array}{c}4 \\
(6.2 \%)\end{array}$ & $\begin{array}{c}57 \\
(87.7 \%)\end{array}$ \\
\hline Sixties pop & $\begin{array}{c}2 \\
(1.7 \%)\end{array}$ & $\begin{array}{c}2 \\
(1.7 \%)\end{array}$ & $\begin{array}{c}114 \\
(96.6 \%)\end{array}$ \\
\hline Indie & $\begin{array}{c}2 \\
(1.6 \%)\end{array}$ & $\begin{array}{c}2 \\
(1.6 \%)\end{array}$ & $\begin{array}{c}124 \\
(96.9 \%)\end{array}$ \\
\hline Adult pop & $\begin{array}{c}2 \\
(1.3 \%)\end{array}$ & $\begin{array}{c}9 \\
(5.8 \%)\end{array}$ & $\begin{array}{c}145 \\
(92.9 \%)\end{array}$ \\
\hline DJ based & $\begin{array}{c}1 \\
(1.5 \%)\end{array}$ & $\begin{array}{c}3 \\
(4.6 \%)\end{array}$ & $\begin{array}{c}61 \\
(93.8 \%)\end{array}$ \\
\hline Other pop & $\begin{array}{c}2 \\
(2.6 \%)\end{array}$ & $\begin{array}{c}10 \\
(12.8 \%)\end{array}$ & $\begin{array}{c}66 \\
(84.6 \%)\end{array}$ \\
\hline Other & $\begin{array}{c}0 \\
(.0 \%)\end{array}$ & $\begin{array}{c}11 \\
(17.2 \%)\end{array}$ & $\begin{array}{c}53 \\
(82.8 \%)\end{array}$ \\
\hline
\end{tabular}

Table 2 - Ethnic background by musical preference 


\begin{tabular}{lccccccccc}
\hline Musical preference & Set 1 & Set 2 & Set 3 & Set 4 & Set 5 & Set 6 & Set 7 & Set 8 & Set 9 \\
\hline Hip hop / rap & 22.33 & & & & & & & & \\
DJ-based & 23.40 & & & & & & & & \\
Dance / house & 23.59 & & & & & & & & \\
R\&B & 24.85 & & & & & & & & \\
Indie & 26.54 & & & & & & & & \\
Current chart pop & 28.45 & 28.45 & & & & & & & \\
Other & & 33.47 & 33.47 & & & & & & \\
Other pop & & 34.10 & 34.10 & 34.10 & & & & & \\
Rock & & 34.51 & 34.51 & 34.51 & & & & & \\
Soul & & & 35.74 & 35.74 & 35.74 & & & & \\
Disco & & & 36.51 & 36.51 & 36.51 & & & & \\
Adult pop & & & & 40.49 & 40.49 & 40.49 & & & \\
Jazz & & & & & 42.11 & 42.11 & 42.11 & & \\
Blues & & & & & & 44.46 & 44.46 & 44.46 & \\
Classical & & & & & & & 47.63 & 47.63 & 47.63 \\
1960s pop & & & & & & & 48.45 & 48.45 & 48.45 \\
Musicals & & & & & & & 49.65 & 49.65 \\
Opera & & & & & & & & 50.30 & 50.30 \\
Country \& western & & & & & & & & & \\
\hline
\end{tabular}

Table 3 - Homogenous sub-sets of means of participant age in years 


\begin{tabular}{|c|c|c|c|}
\hline & Two parents & In a relationship & $\begin{array}{l}\text { Different sex } \\
\text { partner }\end{array}$ \\
\hline Opera & $\begin{array}{c}56 \\
(91.8 \%)\end{array}$ & $\begin{array}{c}38 \\
(62.3 \%)\end{array}$ & $\begin{array}{c}4 \\
(10.0 \%)\end{array}$ \\
\hline $\begin{array}{c}\text { Country \& } \\
\text { western }\end{array}$ & $\begin{array}{c}60 \\
(82.2 \%) \\
\end{array}$ & $\begin{array}{c}52 \\
(73.2 \%) \\
\end{array}$ & $\begin{array}{c}5 \\
(9.4 \%) \\
\end{array}$ \\
\hline Jazz & $\begin{array}{c}67 \\
(93.1 \%) \\
\end{array}$ & $\begin{array}{c}45 \\
(63.4 \%) \\
\end{array}$ & $\begin{array}{c}6 \\
(11.8 \%) \\
\end{array}$ \\
\hline Rock & $\begin{array}{c}180 \\
(93.3 \%)\end{array}$ & $\begin{array}{c}136 \\
(71.6 \%)\end{array}$ & $\begin{array}{c}11 \\
(8.0 \%)\end{array}$ \\
\hline Current chart pop & $\begin{array}{c}118 \\
(89.4 \%)\end{array}$ & $\begin{array}{c}80 \\
(61.5 \%)\end{array}$ & $\begin{array}{c}10 \\
(11.8 \%)\end{array}$ \\
\hline $\mathrm{R} \& \mathrm{~B}$ & $\begin{array}{c}110 \\
(84.6 \%)\end{array}$ & $\begin{array}{c}84 \\
(66.1 \%)\end{array}$ & $\begin{array}{c}5 \\
(6.0 \%)\end{array}$ \\
\hline Soul & $\begin{array}{c}88 \\
(83.8 \%)\end{array}$ & $\begin{array}{c}70 \\
(67.3 \%)\end{array}$ & $\begin{array}{c}10 \\
(13.2 \%)\end{array}$ \\
\hline Classical & $\begin{array}{c}135 \\
(91.8 \%) \\
\end{array}$ & $\begin{array}{c}120 \\
(81.6 \%) \\
\end{array}$ & $\begin{array}{c}9 \\
(7.4 \%) \\
\end{array}$ \\
\hline Disco & $\begin{array}{c}142 \\
(93.4 \%) \\
\end{array}$ & $\begin{array}{c}111 \\
(74.0 \%) \\
\end{array}$ & $\begin{array}{c}14 \\
(11.7 \%) \\
\end{array}$ \\
\hline Dance / house & $\begin{array}{c}105 \\
(80.2 \%)\end{array}$ & $\begin{array}{c}80 \\
(62.0 \%)\end{array}$ & $\begin{array}{c}3 \\
(3.6 \%) \\
\end{array}$ \\
\hline Hip hop / rap & $\begin{array}{c}55 \\
(83.3 \%) \\
\end{array}$ & $\begin{array}{c}40 \\
(60.6 \%) \\
\end{array}$ & $\begin{array}{c}1 \\
(2.8 \%) \\
\end{array}$ \\
\hline Musicals & $\begin{array}{c}114 \\
(94.2 \%)\end{array}$ & $\begin{array}{c}75 \\
(62.5 \%)\end{array}$ & $\begin{array}{c}7 \\
(8.5 \%)\end{array}$ \\
\hline Blues & $\begin{array}{c}59 \\
(90.8 \%)\end{array}$ & $\begin{array}{c}56 \\
(86.2 \%)\end{array}$ & $\begin{array}{c}8 \\
(14.5 \%)\end{array}$ \\
\hline Sixties pop & $\begin{array}{c}103 \\
(88.0 \%)\end{array}$ & $\begin{array}{c}95 \\
(81.2 \%)\end{array}$ & $\begin{array}{c}8 \\
(8.1 \%)\end{array}$ \\
\hline Indie & $\begin{array}{c}111 \\
(86.7 \%)\end{array}$ & $\begin{array}{c}80 \\
(63.0 \%)\end{array}$ & $\begin{array}{c}4 \\
(4.8 \%)\end{array}$ \\
\hline Adult pop & $\begin{array}{c}141 \\
(90.4 \%)\end{array}$ & $\begin{array}{c}121 \\
(78.1 \%)\end{array}$ & $\begin{array}{c}11 \\
(8.7 \%)\end{array}$ \\
\hline DJ based & $\begin{array}{c}56 \\
(86.2 \%)\end{array}$ & $\begin{array}{c}37 \\
(57.8 \%)\end{array}$ & $\begin{array}{c}2 \\
(5.3 \%) \\
\end{array}$ \\
\hline Other pop & $\begin{array}{c}68 \\
(87.2 \%) \\
\end{array}$ & $\begin{array}{c}55 \\
(73.3 \%) \\
\end{array}$ & $\begin{array}{c}3 \\
(5.6 \%) \\
\end{array}$ \\
\hline \multirow[t]{2}{*}{ Other } & $\begin{array}{c}55 \\
(85.9 \%)\end{array}$ & $\begin{array}{c}38 \\
(60.3 \%)\end{array}$ & $\begin{array}{c}2 \\
(5.4 \%)\end{array}$ \\
\hline & $\begin{array}{c}\chi^{2}(18)=36.18, \mathrm{p}< \\
0.01\end{array}$ & $\begin{array}{c}\chi^{2}(18)=59.84, p< \\
0.001\end{array}$ & $\begin{array}{c}\chi^{2}(18)=16.47 \\
\text { n.s. }\end{array}$ \\
\hline
\end{tabular}

Table 4 - Musical preference by type of family during childhood; whether the participant is currently in a romantic relationship; and whether the romantic partner is of the same or different sex 


\begin{tabular}{|c|c|c|c|c|c|c|c|}
\hline & $0-1$ & $2-4$ & $\begin{array}{c}5+ \\
\text { partners }\end{array}$ & $\begin{array}{c}\text { Currently } \\
\text { married }\end{array}$ & $\begin{array}{c}\text { Not } \\
\text { currently } \\
\text { married }\end{array}$ & $\begin{array}{l}\text { Widow / } \\
\text { Widower }\end{array}$ & $\begin{array}{l}\text { Has been } \\
\text { divorced }\end{array}$ \\
\hline Opera & $\begin{array}{c}48 \\
(84.2 \%) \\
\end{array}$ & $\begin{array}{c}7 \\
(12.3 \%) \\
\end{array}$ & $\begin{array}{c}2 \\
(3.5 \%) \\
\end{array}$ & $\begin{array}{c}33 \\
(55.0 \%) \\
\end{array}$ & $\begin{array}{c}20 \\
(33.3 \%) \\
\end{array}$ & $\begin{array}{c}7 \\
(11.7 \%) \\
\end{array}$ & $\begin{array}{c}10 \\
(18.9 \%)\end{array}$ \\
\hline $\begin{array}{c}\text { Country } \\
\& \\
\text { western }\end{array}$ & $\begin{array}{c}58 \\
(85.3 \%)\end{array}$ & $\begin{array}{c}9 \\
(13.2 \%)\end{array}$ & $\begin{array}{c}1 \\
(1.5 \%)\end{array}$ & $\begin{array}{c}47 \\
(66.2 \%)\end{array}$ & $\begin{array}{c}20 \\
(28.2 \%)\end{array}$ & $\begin{array}{c}4 \\
(5.6 \%)\end{array}$ & $\begin{array}{c}12 \\
(17.1 \%)\end{array}$ \\
\hline Jazz & $\begin{array}{c}47 \\
(70.1 \%) \\
\end{array}$ & $\begin{array}{c}11 \\
(16.4 \%)\end{array}$ & $\begin{array}{c}9 \\
(13.5 \%)\end{array}$ & $\begin{array}{c}30 \\
(44.8 \%) \\
\end{array}$ & $\begin{array}{c}32 \\
(47.8 \%)\end{array}$ & $\begin{array}{c}5 \\
(7.5 \%)\end{array}$ & $\begin{array}{c}8 \\
(11.9 \%)\end{array}$ \\
\hline Rock & $\begin{array}{c}134 \\
(72.0 \%)\end{array}$ & $\begin{array}{c}40 \\
(21.5 \%)\end{array}$ & $\begin{array}{c}12 \\
(6.5 \%)\end{array}$ & $\begin{array}{c}71 \\
(38.6 \%)\end{array}$ & $\begin{array}{c}112 \\
(60.9 \%)\end{array}$ & $\begin{array}{c}1 \\
(0.5 \%)\end{array}$ & $\begin{array}{c}29 \\
(15.8 \%)\end{array}$ \\
\hline $\begin{array}{l}\text { Current } \\
\text { chart pop }\end{array}$ & $\begin{array}{c}76 \\
(63.3 \%)\end{array}$ & $\begin{array}{c}27 \\
(22.5 \%)\end{array}$ & $\begin{array}{c}17 \\
(14.2 \%)\end{array}$ & $\begin{array}{c}38 \\
(31.4 \%)\end{array}$ & $\begin{array}{c}82 \\
(67.8 \%)\end{array}$ & $\begin{array}{c}1 \\
(0.8 \%)\end{array}$ & $\begin{array}{c}7 \\
(6.0 \%)\end{array}$ \\
\hline $\mathrm{R} \& \mathrm{~B}$ & $\begin{array}{c}45 \\
(43.3 \%) \\
\end{array}$ & $\begin{array}{c}37 \\
(35.6 \%) \\
\end{array}$ & $\begin{array}{c}22 \\
(21.1 \%) \\
\end{array}$ & $\begin{array}{c}17 \\
(16.2 \%) \\
\end{array}$ & $\begin{array}{c}88 \\
(83.8 \%) \\
\end{array}$ & $\begin{array}{c}0 \\
(0 \%)\end{array}$ & $\begin{array}{c}9 \\
(8.6 \%)\end{array}$ \\
\hline Soul & $\begin{array}{c}59 \\
(56.7 \%)\end{array}$ & $\begin{array}{c}28 \\
(26.9 \%)\end{array}$ & $\begin{array}{c}10 \\
(16.4 \%)\end{array}$ & $\begin{array}{c}41 \\
(41.0 \%)\end{array}$ & $\begin{array}{c}57 \\
(57.0 \%) \\
\end{array}$ & $\begin{array}{c}2 \\
(2.0 \%) \\
\end{array}$ & $\begin{array}{c}15 \\
(15.5 \%)\end{array}$ \\
\hline Classical & $\begin{array}{c}121 \\
(84.0 \%)\end{array}$ & $\begin{array}{c}17 \\
(11.8 \%)\end{array}$ & $\begin{array}{c}6 \\
(4.2 \%)\end{array}$ & $\begin{array}{c}101 \\
(69.7 \%)\end{array}$ & $\begin{array}{c}37 \\
(25.5 \%)\end{array}$ & $\begin{array}{c}7 \\
(4.8 \%)\end{array}$ & $\begin{array}{c}19 \\
(13.5 \%)\end{array}$ \\
\hline Disco & $\begin{array}{c}101 \\
(68.7 \%)\end{array}$ & $\begin{array}{c}30 \\
(20.4 \%)\end{array}$ & $\begin{array}{c}16 \\
(10.9 \%)\end{array}$ & $\begin{array}{c}75 \\
(50.7 \%)\end{array}$ & $\begin{array}{c}70 \\
(47.3 \%)\end{array}$ & $\begin{array}{c}3 \\
(2.0 \%)\end{array}$ & $\begin{array}{c}16 \\
(10.8 \%)\end{array}$ \\
\hline $\begin{array}{c}\text { Dance / } \\
\text { house }\end{array}$ & $\begin{array}{c}44 \\
(38.3 \%)\end{array}$ & $\begin{array}{c}38 \\
(33.0 \%)\end{array}$ & $\begin{array}{c}33 \\
(28.7 \%)\end{array}$ & $\begin{array}{c}9 \\
(7.8 \%)\end{array}$ & $\begin{array}{c}106 \\
(92.2 \%)\end{array}$ & $\begin{array}{c}0 \\
(0 \%) \\
\end{array}$ & $\begin{array}{c}7 \\
(6.1 \%) \\
\end{array}$ \\
\hline $\begin{array}{l}\text { Hip hop / } \\
\text { rap }\end{array}$ & $\begin{array}{c}17 \\
(35.4 \%)\end{array}$ & $\begin{array}{c}13 \\
(27.1 \%)\end{array}$ & $\begin{array}{c}18 \\
(37.5)\end{array}$ & $\begin{array}{c}2 \\
(4.3 \%)\end{array}$ & $\begin{array}{c}44 \\
(95.7 \%)\end{array}$ & $\begin{array}{c}0 \\
(0 \%)\end{array}$ & $\begin{array}{c}3 \\
(6.4 \%)\end{array}$ \\
\hline Musicals & $\begin{array}{c}96 \\
(83.5 \%)\end{array}$ & $\begin{array}{c}13 \\
(11.3 \%)\end{array}$ & $\begin{array}{c}6 \\
(5.2 \%)\end{array}$ & $\begin{array}{c}62 \\
(52.5 \%)\end{array}$ & $\begin{array}{c}39 \\
(33.1 \%)\end{array}$ & $\begin{array}{c}17 \\
(14.4 \%)\end{array}$ & $\begin{array}{c}17 \\
(14.7 \%)\end{array}$ \\
\hline Blues & $\begin{array}{c}49 \\
(76.6 \%)\end{array}$ & $\begin{array}{c}11 \\
(17.2 \%)\end{array}$ & $\begin{array}{c}4 \\
(6.2 \%)\end{array}$ & $\begin{array}{c}43 \\
(66.2 \%)\end{array}$ & $\begin{array}{c}21 \\
(32.3 \%)\end{array}$ & $\begin{array}{c}1 \\
(1.5 \%)\end{array}$ & $\begin{array}{c}10 \\
(15.6 \%)\end{array}$ \\
\hline $\begin{array}{l}\text { Sixties } \\
\text { pop }\end{array}$ & $\begin{array}{c}102 \\
(89.5 \%)\end{array}$ & $\begin{array}{c}11 \\
(9.6 \%)\end{array}$ & $\begin{array}{c}1 \\
(.9 \%)\end{array}$ & $\begin{array}{c}69 \\
(60.5 \%)\end{array}$ & $\begin{array}{c}39 \\
(34.2 \%)\end{array}$ & $\begin{array}{c}6 \\
(5.3 \%)\end{array}$ & $\begin{array}{c}16 \\
(13.9 \%)\end{array}$ \\
\hline Indie & $\begin{array}{c}63 \\
(52.9 \%)\end{array}$ & $\begin{array}{c}35 \\
(29.4 \%)\end{array}$ & $\begin{array}{c}21 \\
(17.7 \%)\end{array}$ & $\begin{array}{c}25 \\
(20.8 \%)\end{array}$ & $\begin{array}{c}94 \\
(78.3 \%)\end{array}$ & $\begin{array}{c}1 \\
(0.8 \%)\end{array}$ & $\begin{array}{c}6 \\
(5.1 \%)\end{array}$ \\
\hline Adult pop & $\begin{array}{c}120 \\
(77.9 \%)\end{array}$ & $\begin{array}{c}23 \\
(14.9 \%)\end{array}$ & $\begin{array}{c}11 \\
(7.2 \%)\end{array}$ & $\begin{array}{c}94 \\
(61.8 \%)\end{array}$ & $\begin{array}{c}58 \\
(38.2 \%)\end{array}$ & $\begin{array}{c}2 \\
(1.3 \%)\end{array}$ & $\begin{array}{c}26 \\
(17.0 \%)\end{array}$ \\
\hline DJ based & $\begin{array}{c}19 \\
(30.6 \%)\end{array}$ & $\begin{array}{c}25 \\
(40.3 \%)\end{array}$ & $\begin{array}{c}18 \\
(29.1 \%)\end{array}$ & $\begin{array}{c}3 \\
(1.9 \%) \\
\end{array}$ & $\begin{array}{c}56 \\
(36.4 \%) \\
\end{array}$ & $\begin{array}{c}1 \\
(0.6 \%) \\
\end{array}$ & $\begin{array}{c}2 \\
(3.4 \%) \\
\end{array}$ \\
\hline Other pop & $\begin{array}{c}52 \\
(70.3 \%)\end{array}$ & $\begin{array}{c}12 \\
(16.2 \%)\end{array}$ & $\begin{array}{c}10 \\
(13.5 \%)\end{array}$ & $\begin{array}{c}28 \\
(43.8 \%)\end{array}$ & $\begin{array}{c}45 \\
(70.3 \%)\end{array}$ & $\begin{array}{c}2 \\
(3.1 \%)\end{array}$ & $\begin{array}{c}8 \\
(10.8 \%)\end{array}$ \\
\hline \multirow[t]{2}{*}{ Other } & $\begin{array}{c}34 \\
(58.6 \%)\end{array}$ & $\begin{array}{c}13 \\
(22.4 \%)\end{array}$ & $\begin{array}{c}11 \\
(19.0 \%)\end{array}$ & $\begin{array}{c}18 \\
(31.6 \%)\end{array}$ & $\begin{array}{c}35 \\
(61.4 \%)\end{array}$ & $\begin{array}{c}4 \\
(7.0 \%)\end{array}$ & $\begin{array}{c}4 \\
(6.9 \%)\end{array}$ \\
\hline & $\begin{array}{c}\chi^{2}(36)= \\
266.51, \mathrm{p} \\
<0.001\end{array}$ & & & $\begin{array}{c}\chi^{2}(36)= \\
432.31, \mathrm{p}< \\
0.001\end{array}$ & & & $\begin{array}{c}\chi^{2}(18)= \\
35.27, \mathrm{p}< \\
0.01\end{array}$ \\
\hline
\end{tabular}

Table 5 - Musical preference by number of sexual partners during past five years; whether the participant is currently married; and has ever been divorced 


\begin{tabular}{|c|c|c|c|c|c|c|c|c|c|c|c|}
\hline & $\begin{array}{c}\text { Living } \\
\text { with } \\
\text { partner }\end{array}$ & $\begin{array}{c}\text { Has or } \\
\text { wants } \\
\text { children }\end{array}$ & & Set 1 & Set 2 & Set 3 & Set 4 & Set 5 & Set 6 & Set 7 & Set 8 \\
\hline Opera & $\begin{array}{c}35 \\
(68.6 \%)\end{array}$ & $\begin{array}{c}52 \\
(86.7 \%)\end{array}$ & $\begin{array}{l}\text { Dance / } \\
\text { house }\end{array}$ & 33.02 & & & & & & & \\
\hline $\begin{array}{c}\text { Country } \\
\& \\
\text { western }\end{array}$ & $\begin{array}{c}53 \\
(76.8 \%)\end{array}$ & $\begin{array}{c}56 \\
(78.9 \%)\end{array}$ & $\begin{array}{l}\text { Hip } \\
\text { hop/rap }\end{array}$ & 41.40 & 41.40 & & & & & & \\
\hline Jazz & $\begin{array}{c}33 \\
(55.0 \%)\end{array}$ & $\begin{array}{c}61 \\
(87.1 \%)\end{array}$ & $\begin{array}{l}\text { DJ } \\
\text { based }\end{array}$ & 45.93 & 45.93 & & & & & & \\
\hline Rock & $\begin{array}{c}101 \\
(58.7 \%)\end{array}$ & $\begin{array}{c}167 \\
(89.8 \%)\end{array}$ & $R \& B$ & 80.54 & 80.54 & 80.54 & & & & & \\
\hline $\begin{array}{c}\text { Current } \\
\text { chart } \\
\text { pop }\end{array}$ & $\begin{array}{c}47 \\
(42.3 \%)\end{array}$ & $\begin{array}{c}105 \\
(83.3 \%)\end{array}$ & Indie & 98.35 & 98.35 & 98.35 & & & & & \\
\hline$R \& B$ & $\begin{array}{c}34 \\
(34.7 \%)\end{array}$ & $\begin{array}{c}105 \\
(86.1 \%)\end{array}$ & $\begin{array}{l}\text { Chart } \\
\text { pop }\end{array}$ & 114.44 & 114.44 & 114.44 & 114.44 & & & & \\
\hline Soul & $\begin{array}{c}49 \\
(55.1 \%)\end{array}$ & $\begin{array}{c}89 \\
(85.6 \%)\end{array}$ & $\begin{array}{l}\text { Other } \\
\text { pop }\end{array}$ & 145.62 & 145.62 & 145.62 & 145.62 & 145.62 & & & \\
\hline Classical & $\begin{array}{c}107 \\
(79.3 \%)\end{array}$ & $\begin{array}{c}127 \\
(86.4 \%)\end{array}$ & Rock & & 163.71 & 163.71 & 163.71 & 163.71 & 163.71 & & \\
\hline Disco & $\begin{array}{c}84 \\
(58.7 \%)\end{array}$ & $\begin{array}{c}128 \\
(86.5 \%)\end{array}$ & Other & & & 173.57 & 173.57 & 173.57 & 173.57 & 173.57 & \\
\hline $\begin{array}{c}\text { Dance / } \\
\text { house }\end{array}$ & $\begin{array}{c}27 \\
(25.2 \%)\end{array}$ & $\begin{array}{c}107 \\
(84.9 \%)\end{array}$ & Soul & & & 180.90 & 180.90 & 180.90 & 180.90 & 180.90 & \\
\hline $\begin{array}{l}\text { Hip hop } \\
\text { / rap }\end{array}$ & $\begin{array}{c}9 \\
(19.6 \%)\end{array}$ & $\begin{array}{c}52 \\
(86.7 \%)\end{array}$ & $\begin{array}{l}\text { Adult } \\
\text { pop }\end{array}$ & & & 181.48 & 181.48 & 181.48 & 181.48 & 181.48 & \\
\hline Musicals & $\begin{array}{c}65 \\
(63.7 \%) \\
\end{array}$ & $\begin{array}{c}98 \\
(82.4 \%)\end{array}$ & Disco & & & 196.72 & 196.72 & 196.72 & 196.72 & 196.72 & \\
\hline Blues & $\begin{array}{c}47 \\
(78.3 \%)\end{array}$ & $\begin{array}{c}52 \\
(81.3 \%)\end{array}$ & Jazz & & & & 235.19 & 235.19 & 235.19 & 235.19 & 235.19 \\
\hline $\begin{array}{l}\text { Sixties } \\
\text { pop }\end{array}$ & $\begin{array}{c}86 \\
(77.5 \%)\end{array}$ & $\begin{array}{c}96 \\
(81.4 \%)\end{array}$ & Blues & & & & & 248.47 & 248.47 & 248.47 & 248.47 \\
\hline Indie & $\begin{array}{c}46 \\
(42.2 \%) \\
\end{array}$ & $\begin{array}{c}107 \\
(90.7 \%)\end{array}$ & $\begin{array}{l}\text { Sixties } \\
\text { pop }\end{array}$ & & & & & 261.89 & 261.89 & 261.89 & 261.89 \\
\hline $\begin{array}{l}\text { Adult } \\
\text { pop }\end{array}$ & $\begin{array}{c}111 \\
(74.0 \%)\end{array}$ & $\begin{array}{c}140 \\
(90.9 \%)\end{array}$ & Classical & & & & & & 279.79 & 279.79 & 279.79 \\
\hline $\begin{array}{c}\text { DJ } \\
\text { based }\end{array}$ & $\begin{array}{c}13 \\
(25.5 \%)\end{array}$ & $\begin{array}{c}55 \\
(85.9 \%)\end{array}$ & $\begin{array}{l}\text { Country } \\
\& \\
\text { western }\end{array}$ & & & & & & & 298.00 & 298.00 \\
\hline $\begin{array}{l}\text { Other } \\
\text { pop }\end{array}$ & $\begin{array}{c}35 \\
(49.3 \%) \\
\end{array}$ & $\begin{array}{c}65 \\
(86.7 \%) \\
\end{array}$ & Opera & & & & & & & & 322.68 \\
\hline \multirow[t]{2}{*}{ Other } & $\begin{array}{c}22 \\
(39.3 \%)\end{array}$ & $\begin{array}{c}52 \\
(83.9 \%)\end{array}$ & Musicals & & & & & & & & 322.77 \\
\hline & $\begin{array}{c}\chi^{2}(18) \\
= \\
228.94 \\
\mathrm{p}< \\
0.001\end{array}$ & $\begin{array}{c}\chi^{2}(18) \\
= \\
16.33 \\
\text { n.s. }\end{array}$ & & & & & & & & & \\
\hline
\end{tabular}

Table 6 - Musical preference by whether the participant is currently living with their romantic partner; and has or wants to have children; and homogenous sub-sets of means of number of months for which participants had lived with their romantic partner 


\begin{tabular}{lcclcc}
\hline & More friends & & & Outgoing \\
\hline Musical preference & Set 1 & Set 2 & & Set 1 & Set 2 \\
\hline Classical & 4.49 & & Musicals & 5.74 & \\
Blues & 4.78 & 4.78 & Classical & 5.75 & \\
Country \& western & 4.83 & 4.83 & Opera & 5.78 & \\
Adult pop & 4.84 & 4.84 & Country \& western & 5.84 & \\
Opera & 4.90 & 4.90 & Adult pop & 5.88 & 5.88 \\
Rock & 4.99 & 4.99 & Blues & 5.95 & 5.95 \\
1960s pop & 4.99 & 4.99 & Sixties pop & 5.99 & 5.99 \\
Other pop & 5.03 & 5.03 & Rock & 6.14 & 6.14 \\
Jazz & 5.08 & 5.08 & Indie & 6.35 & 6.35 \\
Soul & 5.12 & 5.12 & Other pop & 6.36 & 6.36 \\
Musicals & 5.22 & 5.22 & Jazz & 6.38 & 6.38 \\
Other & 5.27 & 5.27 & Soul & 6.54 & 6.54 \\
DJ-based & 5.28 & 5.28 & Other & 6.65 & 6.65 \\
Disco & 5.38 & 5.38 & Disco & 6.81 & 6.81 \\
Current chart pop & 5.53 & 5.53 & R\&B & 7.13 & 7.13 \\
Indie & 5.63 & 5.63 & Hip hop/rap & 7.21 & 7.21 \\
Hip hop / rap & & 5.85 & Current chart pop & 7.31 & 7.31 \\
R\&B & & 5.86 & DJ based & 7.74 & 7.74 \\
Dance / house & & 5.95 & Dance / house & & 8.11 \\
\hline
\end{tabular}

Table 7 - Homogenous sub-sets of means of the extent to which participants would like to have more friends and the extent to which participants' friends are outgoing 


\begin{tabular}{|c|c|}
\hline & Owns home \\
\hline Opera & 46 \\
$(76.7 \%)$
\end{tabular}

\begin{tabular}{|c|c|c|c|}
\hline Lives in terrace & $\begin{array}{l}\text { Lives in semi- } \\
\text { detached }\end{array}$ & $\begin{array}{l}\text { Lives in } \\
\text { detached }\end{array}$ & $\begin{array}{c}\text { Lives in } \\
\text { flat }\end{array}$ \\
\hline $\begin{array}{c}10 \\
(16.4 \%)\end{array}$ & $\begin{array}{c}18 \\
(29.5 \%)\end{array}$ & $\begin{array}{c}23 \\
(37.7 \%)\end{array}$ & $\begin{array}{c}6 \\
(9.8 \%)\end{array}$ \\
\hline $\begin{array}{c}13 \\
(18.1 \%)\end{array}$ & $\begin{array}{c}37 \\
(51.4 \%)\end{array}$ & $\begin{array}{c}16 \\
(22.2 \%)\end{array}$ & $\begin{array}{c}3 \\
(4.2 \%)\end{array}$ \\
\hline $\begin{array}{c}11 \\
(15.7 \%)\end{array}$ & $\begin{array}{c}20 \\
(28.6 \%)\end{array}$ & $\begin{array}{c}25 \\
(35.7 \%)\end{array}$ & $\begin{array}{c}9 \\
(12.9 \%)\end{array}$ \\
\hline $\begin{array}{c}36 \\
(18.8 \%)\end{array}$ & $\begin{array}{c}73 \\
(38.0 \%)\end{array}$ & $\begin{array}{c}57 \\
(29.7 \%)\end{array}$ & $\begin{array}{c}23 \\
(12.0 \%)\end{array}$ \\
\hline $\begin{array}{c}32 \\
(24.8 \%)\end{array}$ & $\begin{array}{c}52 \\
(40.3 \%)\end{array}$ & $\begin{array}{c}29 \\
(22.5 \%)\end{array}$ & $\begin{array}{c}11 \\
(8.5 \%)\end{array}$ \\
\hline $\begin{array}{c}40 \\
(31.7 \%)\end{array}$ & $\begin{array}{c}48 \\
(38.1 \%)\end{array}$ & $\begin{array}{c}24 \\
(19.0 \%)\end{array}$ & $\begin{array}{c}13 \\
(10.3 \%)\end{array}$ \\
\hline $\begin{array}{c}25 \\
(24.0 \%)\end{array}$ & $\begin{array}{c}33 \\
(31.7 \%) \\
\end{array}$ & $\begin{array}{c}30 \\
(28.8 \%) \\
\end{array}$ & $\begin{array}{c}12 \\
(11.5 \%)\end{array}$ \\
\hline $\begin{array}{c}20 \\
(13.8 \%)\end{array}$ & $\begin{array}{c}41 \\
(28.3 \%)\end{array}$ & $\begin{array}{c}55 \\
(37.9 \%)\end{array}$ & $\begin{array}{c}17 \\
(11.7 \%)\end{array}$ \\
\hline $\begin{array}{c}35 \\
(23.3 \%)\end{array}$ & $\begin{array}{c}59 \\
(39.3 \%)\end{array}$ & $\begin{array}{c}45 \\
(30.0 \%)\end{array}$ & $\begin{array}{c}7 \\
(4.7 \%)\end{array}$ \\
\hline $\begin{array}{c}31 \\
(24.4 \%)\end{array}$ & $\begin{array}{c}54 \\
(42.5 \%)\end{array}$ & $\begin{array}{c}26 \\
(20.5 \%)\end{array}$ & $\begin{array}{c}11 \\
(8.7 \%)\end{array}$ \\
\hline $\begin{array}{c}19 \\
(29.7 \%)\end{array}$ & $\begin{array}{c}15 \\
(23.4 \%)\end{array}$ & $\begin{array}{c}22 \\
(34.4 \%)\end{array}$ & $\begin{array}{c}7 \\
(10.9 \%)\end{array}$ \\
\hline $\begin{array}{c}21 \\
(17.6 \%)\end{array}$ & $\begin{array}{c}38 \\
(31.9 \%) \\
\end{array}$ & $\begin{array}{c}40 \\
(33.6 \%)\end{array}$ & $\begin{array}{c}13 \\
(10.9 \%)\end{array}$ \\
\hline $\begin{array}{c}16 \\
(25.4 \%) \\
\end{array}$ & $\begin{array}{c}19 \\
(30.2 \%)\end{array}$ & $\begin{array}{c}21 \\
(33.3 \%)\end{array}$ & $\begin{array}{c}7 \\
(11.1 \%)\end{array}$ \\
\hline $\begin{array}{c}22 \\
(18.6 \%)\end{array}$ & $\begin{array}{c}48 \\
(40.7 \%)\end{array}$ & $\begin{array}{c}29 \\
(24.6 \%)\end{array}$ & $\begin{array}{c}10 \\
(8.5 \%)\end{array}$ \\
\hline $\begin{array}{c}26 \\
(20.6 \%)\end{array}$ & $\begin{array}{c}51 \\
(40.5 \%)\end{array}$ & $\begin{array}{c}31 \\
(24.6 \%)\end{array}$ & $\begin{array}{c}13 \\
(10.3 \%)\end{array}$ \\
\hline $\begin{array}{c}30 \\
(19.2 \%)\end{array}$ & $\begin{array}{c}56 \\
(35.9 \%)\end{array}$ & $\begin{array}{c}55 \\
(35.3 \%)\end{array}$ & $\begin{array}{c}13 \\
(8.3 \%)\end{array}$ \\
\hline $\begin{array}{c}14 \\
(21.9 \%)\end{array}$ & $\begin{array}{c}19 \\
(29.7 \%)\end{array}$ & $\begin{array}{c}20 \\
(31.3 \%)\end{array}$ & $\begin{array}{c}11 \\
(17.2 \%)\end{array}$ \\
\hline $\begin{array}{c}14 \\
(18.7 \%)\end{array}$ & $\begin{array}{c}23 \\
(30.7 \%)\end{array}$ & $\begin{array}{c}29 \\
(38.7 \%)\end{array}$ & $\begin{array}{c}9 \\
(12.0 \%)\end{array}$ \\
\hline $\begin{array}{c}14 \\
(22.6 \%)\end{array}$ & $\begin{array}{c}21 \\
(33.9 \%)\end{array}$ & $\begin{array}{c}14 \\
(22.6 \%)\end{array}$ & $\begin{array}{c}13 \\
(21.0 \%)\end{array}$ \\
\hline $\begin{array}{c}\chi^{2}(54)=83.82, p< \\
0.01\end{array}$ & & & \\
\hline
\end{tabular}

Table 8 - Musical preference by whether the participant owns their own home and what type of home the participant lives in 


\begin{tabular}{|c|c|}
\hline & Yes \\
\hline Opera & $\begin{array}{c}41 \\
(67.2 \%)\end{array}$ \\
\hline Country \& western & $\begin{array}{c}46 \\
(63.9 \%)\end{array}$ \\
\hline Jazz & $\begin{array}{c}51 \\
(71.8 \%)\end{array}$ \\
\hline Rock & $\begin{array}{c}151 \\
(78.6 \%)\end{array}$ \\
\hline Current chart pop & $\begin{array}{c}108 \\
(83.1 \%)\end{array}$ \\
\hline $\mathrm{R} \& \mathrm{~B}$ & $\begin{array}{c}105 \\
(82.0 \%)\end{array}$ \\
\hline Soul & $\begin{array}{c}76 \\
(72.4 \%)\end{array}$ \\
\hline Classical & $\begin{array}{c}101 \\
(69.2 \%)\end{array}$ \\
\hline Disco & $\begin{array}{c}119 \\
(78.8 \%)\end{array}$ \\
\hline Dance / house & $\begin{array}{c}100 \\
(77.5 \%)\end{array}$ \\
\hline Hip hop / rap & $\begin{array}{c}50 \\
(76.9 \%) \\
\end{array}$ \\
\hline Musicals & $\begin{array}{c}81 \\
(67.5 \%) \\
\end{array}$ \\
\hline Blues & $\begin{array}{c}41 \\
(63.1 \%) \\
\end{array}$ \\
\hline Sixties pop & $\begin{array}{c}91 \\
(77.1 \%) \\
\end{array}$ \\
\hline Indie & $\begin{array}{c}98 \\
(77.2 \%)\end{array}$ \\
\hline Adult pop & $\begin{array}{c}116 \\
(74.4 \%)\end{array}$ \\
\hline DJ based & $\begin{array}{c}45 \\
(70.3 \%)\end{array}$ \\
\hline Other pop & $\begin{array}{c}59 \\
(78.7 \%) \\
\end{array}$ \\
\hline \multirow[t]{2}{*}{ Other } & $\begin{array}{c}49 \\
(79.0 \%)\end{array}$ \\
\hline & $\chi^{2}(18)=32.11, p<0.05$ \\
\hline
\end{tabular}

Table 9 - Have you spent more than half your life in the same TV region in which you were born by musical preference 


\begin{tabular}{|c|c|c|c|c|c|c|c|c|c|c|}
\hline & $\begin{array}{l}\text { Other } \\
\text { people }\end{array}$ & & & & & & $£ 1000+$ & & & \\
\hline Musical preference & Set 1 & Set 2 & Set 3 & Set 4 & Set 5 & & Set 1 & Set 2 & Set 3 & Set 4 \\
\hline Country \& western & 2.49 & & & & & Jazz & 1.55 & & & \\
\hline Opera & 2.49 & & & & & Opera & 1.67 & 1.67 & & \\
\hline Jazz & 2.63 & 2.63 & & & & Musicals & 1.71 & 1.71 & 1.71 & \\
\hline Classical & 2.69 & 2.69 & & & & Classical & 1.71 & 1.71 & 1.71 & \\
\hline 1960s pop & 2.81 & 2.81 & 2.81 & & & Other pop & 1.75 & 1.75 & 1.75 & \\
\hline Adult pop & 2.85 & 2.85 & 2.85 & & & Blues & 1.78 & 1.78 & 1.78 & \\
\hline Musicals & 2.86 & 2.86 & 2.86 & & & Country \& western & 1.79 & 1.79 & 1.79 & \\
\hline Blues & 2.88 & 2.88 & 2.88 & & & Adult pop & 1.82 & 1.82 & 1.82 & 1.82 \\
\hline Other pop & 2.93 & 2.93 & 2.93 & 2.93 & & Disco & 1.82 & 1.82 & 1.82 & 1.82 \\
\hline Rock & 3.17 & 3.17 & 3.17 & 3.17 & & Other & 1.84 & 1.84 & 1.84 & 1.84 \\
\hline Soul & 3.19 & 3.19 & 3.19 & 3.19 & & Sixties pop & 1.91 & 1.91 & 1.91 & 1.91 \\
\hline Indie & 3.35 & 3.35 & 3.35 & 3.35 & 3.35 & Rock & 1.94 & 1.94 & 1.94 & 1.94 \\
\hline Disco & 3.39 & 3.39 & 3.39 & 3.39 & 3.39 & Current chart pop & 1.95 & 1.95 & 1.95 & 1.95 \\
\hline Other & 3.42 & 3.42 & 3.42 & 3.42 & 3.42 & Indie & 1.96 & 1.96 & 1.96 & 1.96 \\
\hline Current chart pop & 3.48 & 3.48 & 3.48 & 3.48 & 3.48 & DJ based & 2.03 & 2.03 & 2.03 & 2.03 \\
\hline$R \& B$ & & 3.71 & 3.71 & 3.71 & 3.71 & Soul & 2.07 & 2.07 & 2.07 & 2.07 \\
\hline Dance / house & & & 3.86 & 3.86 & 3.86 & $R \& B$ & & 2.13 & 2.13 & 2.13 \\
\hline DJ-based & & & & 4.03 & 4.03 & Dance / house & & & 2.22 & 2.22 \\
\hline Hip hop / rap & & & & & 4.33 & Hip hop/rap & & & & 2.36 \\
\hline
\end{tabular}

Table 10 - Homogenous sub-sets of means of the number of other people living in the participant's home and the number of people living in the participant's home with an annual income in excess of $£ 1000$ per annum 


\begin{tabular}{|c|c|c|c|c|c|}
\hline & Labour & Conservative & Liberal & Don't vote & No preference \\
\hline Opera & $\begin{array}{c}20 \\
(32.8 \%)\end{array}$ & $\begin{array}{c}21 \\
(34.4 \%)\end{array}$ & $\begin{array}{c}5 \\
(8.2 \%)\end{array}$ & $\begin{array}{c}6 \\
(9.8 \%)\end{array}$ & $\begin{array}{c}5 \\
(8.2 \%)\end{array}$ \\
\hline Country \& western & $\begin{array}{c}23 \\
(32.9 \%)\end{array}$ & $\begin{array}{c}25 \\
(35.7 \%)\end{array}$ & $\begin{array}{c}7 \\
(10.0 \%)\end{array}$ & $\begin{array}{c}9 \\
(12.9 \%)\end{array}$ & $\begin{array}{c}3 \\
(4.3 \%) \\
\end{array}$ \\
\hline Jazz & $\begin{array}{c}23 \\
(33.3 \%) \\
\end{array}$ & $\begin{array}{c}23 \\
(33.3 \%)\end{array}$ & $\begin{array}{c}8 \\
(11.6 \%)\end{array}$ & $\begin{array}{c}3 \\
(4.3 \%)\end{array}$ & $\begin{array}{c}9 \\
(13.0 \%)\end{array}$ \\
\hline Rock & $\begin{array}{c}53 \\
(28.0 \%)\end{array}$ & $\begin{array}{c}45 \\
(23.8 \%)\end{array}$ & $\begin{array}{c}25 \\
(13.2 \%)\end{array}$ & $\begin{array}{c}36 \\
(19.0 \%)\end{array}$ & $\begin{array}{c}28 \\
(14.8 \%)\end{array}$ \\
\hline Current chart pop & $\begin{array}{c}33 \\
(26.6 \%)\end{array}$ & $\begin{array}{c}27 \\
(21.8 \%)\end{array}$ & $\begin{array}{c}14 \\
(11.3 \%)\end{array}$ & $\begin{array}{c}32 \\
(25.8 \%)\end{array}$ & $\begin{array}{c}16 \\
(12.9 \%)\end{array}$ \\
\hline $\mathrm{R} \& \mathrm{~B}$ & $\begin{array}{c}33 \\
(27.0 \%) \\
\end{array}$ & $\begin{array}{c}25 \\
(20.5 \%)\end{array}$ & $\begin{array}{c}9 \\
(7.4 \%) \\
\end{array}$ & $\begin{array}{c}28 \\
(23.0 \%)\end{array}$ & $\begin{array}{c}25 \\
(20.5 \%)\end{array}$ \\
\hline Soul & $\begin{array}{c}34 \\
(33.0 \%)\end{array}$ & $\begin{array}{c}27 \\
(26.2 \%)\end{array}$ & $\begin{array}{c}9 \\
(8.7 \%)\end{array}$ & $\begin{array}{c}16 \\
(15.5 \%)\end{array}$ & $\begin{array}{c}15 \\
(14.6 \%)\end{array}$ \\
\hline Classical & $\begin{array}{c}50 \\
(36.2 \%) \\
\end{array}$ & $\begin{array}{c}42 \\
(30.4 \%) \\
\end{array}$ & $\begin{array}{c}13 \\
(9.4 \%) \\
\end{array}$ & $\begin{array}{c}12 \\
(8.7 \%)\end{array}$ & $\begin{array}{c}17 \\
(12.3 \%)\end{array}$ \\
\hline Disco & $\begin{array}{c}46 \\
(31.5 \%) \\
\end{array}$ & $\begin{array}{c}34 \\
(23.3 \%) \\
\end{array}$ & $\begin{array}{c}16 \\
(11.0 \%)\end{array}$ & $\begin{array}{c}24 \\
(16.4 \%)\end{array}$ & $\begin{array}{c}22 \\
(15.1 \%) \\
\end{array}$ \\
\hline Dance / house & $\begin{array}{c}32 \\
(27.4 \%)\end{array}$ & $\begin{array}{c}18 \\
(15.4 \%)\end{array}$ & $\begin{array}{c}9 \\
(7.7 \%) \\
\end{array}$ & $\begin{array}{c}30 \\
(25.6 \%) \\
\end{array}$ & $\begin{array}{c}28 \\
(23.9 \%) \\
\end{array}$ \\
\hline Hip hop / rap & $\begin{array}{c}19 \\
(29.7 \%)\end{array}$ & $\begin{array}{c}7 \\
(10.9 \%)\end{array}$ & $\begin{array}{c}5 \\
(7.8 \%)\end{array}$ & $\begin{array}{c}18 \\
(28.1 \%)\end{array}$ & $\begin{array}{c}15 \\
(23.4 \%)\end{array}$ \\
\hline Musicals & $\begin{array}{c}38 \\
(31.9 \%)\end{array}$ & $\begin{array}{c}35 \\
(29.4 \%) \\
\end{array}$ & $\begin{array}{c}11 \\
(9.2 \%) \\
\end{array}$ & $\begin{array}{c}18 \\
(15.1 \%) \\
\end{array}$ & $\begin{array}{c}15 \\
(12.6 \%)\end{array}$ \\
\hline Blues & $\begin{array}{c}23 \\
(36.5 \%) \\
\end{array}$ & $\begin{array}{c}18 \\
(28.6 \%) \\
\end{array}$ & $\begin{array}{c}7 \\
(11.1 \%) \\
\end{array}$ & $\begin{array}{c}6 \\
(9.5 \%) \\
\end{array}$ & $\begin{array}{c}8 \\
(12.7 \%) \\
\end{array}$ \\
\hline Sixties pop & $\begin{array}{c}51 \\
(45.5 \%) \\
\end{array}$ & $\begin{array}{c}29 \\
(25.9 \%) \\
\end{array}$ & $\begin{array}{c}13 \\
(11.6 \%)\end{array}$ & $\begin{array}{c}9 \\
(8.0 \%) \\
\end{array}$ & $\begin{array}{c}6 \\
(5.4 \%) \\
\end{array}$ \\
\hline Indie & $\begin{array}{c}36 \\
(28.8 \%) \\
\end{array}$ & $\begin{array}{c}16 \\
(12.8 \%) \\
\end{array}$ & $\begin{array}{c}18 \\
(14.4 \%) \\
\end{array}$ & $\begin{array}{c}25 \\
(20.0 \%)\end{array}$ & $\begin{array}{c}26 \\
(20.8 \%) \\
\end{array}$ \\
\hline Adult pop & $\begin{array}{c}51 \\
(34.0 \%)\end{array}$ & $\begin{array}{c}38 \\
(25.3 \%)\end{array}$ & $\begin{array}{c}17 \\
(11.3 \%)\end{array}$ & $\begin{array}{c}19 \\
(12.7 \%)\end{array}$ & $\begin{array}{c}22 \\
(14.7 \%)\end{array}$ \\
\hline DJ based & $\begin{array}{c}13 \\
(20.6 \%)\end{array}$ & $\begin{array}{c}12 \\
(19.0 \%)\end{array}$ & $\begin{array}{c}2 \\
(3.2 \%) \\
\end{array}$ & $\begin{array}{c}23 \\
(36.5 \%)\end{array}$ & $\begin{array}{c}11 \\
(17.5 \%)\end{array}$ \\
\hline Other pop & $\begin{array}{c}18 \\
(24.7 \%)\end{array}$ & $\begin{array}{c}18 \\
(24.7 \%)\end{array}$ & $\begin{array}{c}7 \\
(9.6 \%)\end{array}$ & $\begin{array}{c}16 \\
(21.9 \%)\end{array}$ & $\begin{array}{c}14 \\
(19.2 \%)\end{array}$ \\
\hline Other & $\begin{array}{c}16 \\
(25.0 \%)\end{array}$ & $\begin{array}{c}12 \\
(18.8 \%)\end{array}$ & $\begin{array}{c}9 \\
(14.1 \%)\end{array}$ & $\begin{array}{c}11 \\
(17.2 \%)\end{array}$ & $\begin{array}{c}14 \\
(21.9 \%)\end{array}$ \\
\hline
\end{tabular}

Table 11 - Musical preference by participants' voting preferences 


\begin{tabular}{|c|c|c|c|c|c|c|}
\hline & $\begin{array}{l}\text { Vegetarian } \\
\text { / vegan }\end{array}$ & None & Protestant & Catholic & Other & $\begin{array}{c}\text { Worships } \\
\text { as } \\
\text { regularly } \\
\text { as should }\end{array}$ \\
\hline Opera & $\begin{array}{c}10 \\
(17.2 \%)\end{array}$ & $\begin{array}{c}19 \\
(31.7 \%)\end{array}$ & $\begin{array}{c}21 \\
(35.0 \%)\end{array}$ & $\begin{array}{c}12 \\
(20.0 \%)\end{array}$ & $\begin{array}{c}8 \\
(13.4 \%)\end{array}$ & $\begin{array}{c}18 \\
(43.9 \%)\end{array}$ \\
\hline $\begin{array}{c}\text { Country } \\
\& \\
\text { western }\end{array}$ & $\begin{array}{c}9 \\
(13.8 \%)\end{array}$ & $\begin{array}{c}17 \\
(25.0 \%)\end{array}$ & $\begin{array}{c}25 \\
(36.8 \%)\end{array}$ & $\begin{array}{c}14 \\
(20.6 \%)\end{array}$ & $\begin{array}{c}12 \\
(17.6 \%)\end{array}$ & $\begin{array}{c}13 \\
(27.1 \%)\end{array}$ \\
\hline Jazz & $\begin{array}{c}6 \\
(9.1 \%)\end{array}$ & $\begin{array}{c}23 \\
(34.3 \%)\end{array}$ & $\begin{array}{c}24 \\
(35.8 \%)\end{array}$ & $\begin{array}{c}11 \\
(16.4 \%)\end{array}$ & $\begin{array}{c}9 \\
(13.4 \%)\end{array}$ & $\begin{array}{c}16 \\
(34.0 \%)\end{array}$ \\
\hline Rock & $\begin{array}{c}19 \\
(10.2 \%)\end{array}$ & $\begin{array}{c}69 \\
(37.1 \%)\end{array}$ & $\begin{array}{c}87 \\
(46.8 \%)\end{array}$ & $\begin{array}{c}14 \\
(7.5 \%)\end{array}$ & $\begin{array}{c}16 \\
(8.7 \%)\end{array}$ & $\begin{array}{c}29 \\
(25.0 \%)\end{array}$ \\
\hline $\begin{array}{c}\text { Current } \\
\text { chart } \\
\text { pop }\end{array}$ & $\begin{array}{c}17 \\
(13.9 \%)\end{array}$ & $\begin{array}{c}38 \\
(30.6 \%)\end{array}$ & $\begin{array}{c}48 \\
(38.7 \%)\end{array}$ & $\begin{array}{c}16 \\
(12.9 \%)\end{array}$ & $\begin{array}{c}22 \\
(17.7 \%)\end{array}$ & $\begin{array}{c}19 \\
(22.4 \%)\end{array}$ \\
\hline$R \& B$ & $\begin{array}{c}22 \\
(18.3 \%)\end{array}$ & $\begin{array}{c}42 \\
(33.9 \%)\end{array}$ & $\begin{array}{c}34 \\
(27.4 \%)\end{array}$ & $\begin{array}{c}14 \\
(11.3 \%)\end{array}$ & $\begin{array}{c}34 \\
(27.4 \%)\end{array}$ & $\begin{array}{c}12 \\
(15.8 \%)\end{array}$ \\
\hline Soul & $\begin{array}{c}23 \\
(23.2 \%) \\
\end{array}$ & $\begin{array}{c}37 \\
(36.3 \%) \\
\end{array}$ & $\begin{array}{c}37 \\
(36.3 \%)\end{array}$ & $\begin{array}{c}12 \\
(11.8 \%) \\
\end{array}$ & $\begin{array}{c}16 \\
(15.6 \%) \\
\end{array}$ & $\begin{array}{c}12 \\
(19.3 \%) \\
\end{array}$ \\
\hline Classical & $\begin{array}{c}17 \\
(12.5 \%)\end{array}$ & $\begin{array}{c}42 \\
(29.4 \%)\end{array}$ & $\begin{array}{c}62 \\
(43.4 \%)\end{array}$ & $\begin{array}{c}20 \\
(14.0 \%)\end{array}$ & $\begin{array}{c}3 \\
(13.3 \%)\end{array}$ & $\begin{array}{c}33 \\
(35.5 \%)\end{array}$ \\
\hline Disco & $\begin{array}{c}10 \\
(7.1 \%)\end{array}$ & $\begin{array}{c}40 \\
(27.8 \%)\end{array}$ & $\begin{array}{c}62 \\
(43.1 \%)\end{array}$ & $\begin{array}{c}18 \\
(12.5 \%)\end{array}$ & $\begin{array}{c}24 \\
(16.7 \%)\end{array}$ & $\begin{array}{c}12 \\
(13.0 \%)\end{array}$ \\
\hline $\begin{array}{c}\text { Dance / } \\
\text { house }\end{array}$ & $\begin{array}{c}15 \\
(12.9 \%)\end{array}$ & $\begin{array}{c}52 \\
(43.3 \%)\end{array}$ & $\begin{array}{c}39 \\
(32.5 \%)\end{array}$ & $\begin{array}{c}8 \\
(6.7 \%)\end{array}$ & $\begin{array}{c}21 \\
(17.4 \%)\end{array}$ & $\begin{array}{c}11 \\
(17.2 \%)\end{array}$ \\
\hline $\begin{array}{l}\text { Hip hop } \\
\text { / rap }\end{array}$ & $\begin{array}{c}10 \\
(16.1 \%)\end{array}$ & $\begin{array}{c}20 \\
(32.3 \%)\end{array}$ & $\begin{array}{c}12 \\
(19.4 \%)\end{array}$ & $\begin{array}{c}5 \\
(8.1 \%)\end{array}$ & $\begin{array}{c}25 \\
(40.3 \%)\end{array}$ & $\begin{array}{c}7 \\
(18.4 \%)\end{array}$ \\
\hline Musicals & $\begin{array}{c}11 \\
(9.5 \%)\end{array}$ & $\begin{array}{c}28 \\
(23.3 \%)\end{array}$ & $\begin{array}{c}58 \\
(48.3 \%)\end{array}$ & $\begin{array}{c}17 \\
(14.2 \%)\end{array}$ & $\begin{array}{c}17 \\
(14.1 \%)\end{array}$ & $\begin{array}{c}37 \\
(39.8 \%)\end{array}$ \\
\hline Blues & $\begin{array}{c}8 \\
(12.9 \%)\end{array}$ & $\begin{array}{c}20 \\
(30.8 \%)\end{array}$ & $\begin{array}{c}26 \\
(40.0 \%)\end{array}$ & $\begin{array}{c}12 \\
(18.5 \%)\end{array}$ & $\begin{array}{c}7 \\
(10.7 \%)\end{array}$ & $\begin{array}{c}11 \\
(27.5 \%)\end{array}$ \\
\hline $\begin{array}{l}\text { Sixties } \\
\text { pop }\end{array}$ & $\begin{array}{c}9 \\
(8.0 \%)\end{array}$ & $\begin{array}{c}41 \\
(36.0 \%)\end{array}$ & $\begin{array}{c}46 \\
(40.4 \%)\end{array}$ & $\begin{array}{c}15 \\
(13.2 \%)\end{array}$ & $\begin{array}{c}12 \\
(10.6 \%)\end{array}$ & $\begin{array}{c}13 \\
(19.7 \%)\end{array}$ \\
\hline Indie & $\begin{array}{c}18 \\
(15.3 \%) \\
\end{array}$ & $\begin{array}{c}55 \\
(44.4 \%) \\
\end{array}$ & $\begin{array}{c}53 \\
(42.7 \%) \\
\end{array}$ & $\begin{array}{c}10 \\
(8.1 \%)\end{array}$ & $\begin{array}{c}6 \\
(4.8 \%) \\
\end{array}$ & $\begin{array}{c}15 \\
(24.2 \%) \\
\end{array}$ \\
\hline $\begin{array}{l}\text { Adult } \\
\text { pop }\end{array}$ & $\begin{array}{c}12 \\
(8.3 \%)\end{array}$ & $\begin{array}{c}45 \\
(30.0 \%) \\
\end{array}$ & $\begin{array}{c}70 \\
(46.7 \%) \\
\end{array}$ & $\begin{array}{c}20 \\
(13.3 \%)\end{array}$ & $\begin{array}{c}15 \\
(10.0 \%)\end{array}$ & $\begin{array}{c}20 \\
(21.3 \%) \\
\end{array}$ \\
\hline $\begin{array}{c}\text { DJ } \\
\text { based }\end{array}$ & $\begin{array}{c}4 \\
(7.0 \%)\end{array}$ & $\begin{array}{c}33 \\
(55.0 \%)\end{array}$ & $\begin{array}{c}15 \\
(25.0 \%)\end{array}$ & $\begin{array}{c}7 \\
(11.7 \%)\end{array}$ & $\begin{array}{c}5 \\
(8.4 \%) \\
\end{array}$ & $\begin{array}{c}4 \\
(20.0 \%)\end{array}$ \\
\hline $\begin{array}{l}\text { Other } \\
\text { pop }\end{array}$ & $\begin{array}{c}6 \\
(8.2 \%)\end{array}$ & $\begin{array}{c}27 \\
(38.6 \%)\end{array}$ & $\begin{array}{c}23 \\
(32.9 \%)\end{array}$ & $\begin{array}{c}6 \\
(8.6 \%)\end{array}$ & $\begin{array}{c}14 \\
(20.0 \%)\end{array}$ & $\begin{array}{c}8 \\
(18.6 \%)\end{array}$ \\
\hline \multirow[t]{2}{*}{ Other } & $\begin{array}{c}9 \\
(14.5 \%)\end{array}$ & $\begin{array}{c}21 \\
(33.9 \%)\end{array}$ & $\begin{array}{c}18 \\
(29.0 \%)\end{array}$ & $\begin{array}{c}10 \\
(16.1 \%)\end{array}$ & $\begin{array}{c}14 \\
(21.0 \%)\end{array}$ & $\begin{array}{c}16 \\
(41.0 \%)\end{array}$ \\
\hline & $\begin{array}{c}\chi^{2}(18)= \\
31.36, \mathrm{p}< \\
0.05\end{array}$ & $\begin{array}{c}\chi^{2}(54) \\
= \\
138.95 \\
\mathrm{p}< \\
0.001\end{array}$ & & & & $\begin{array}{c}\chi^{2}(18)= \\
49.30, \mathrm{p} \\
<0.001\end{array}$ \\
\hline
\end{tabular}

Table 12 - Musical preference by whether the participant is vegetarian / vegan; religious affiliation; and whether the participant worships as regularly as their religion says they should 


\begin{tabular}{|l|l|l|l|}
\hline Musical preference & Set 1 & Set 2 & Set 3 \\
\hline DJ based & 1.40 & & \\
\hline Hip hop / rap & 1.56 & 1.56 & \\
\hline R\&B & 1.67 & 1.67 & \\
\hline Indie & 1.79 & 1.79 & 1.79 \\
\hline Dance / house & 1.82 & 1.82 & 1.82 \\
\hline Current chart pop & 1.83 & 1.83 & 1.83 \\
\hline Other & 1.84 & 1.84 & 1.84 \\
\hline Disco & 1.87 & 1.87 & 1.87 \\
\hline Rock & 1.99 & 1.99 & 1.99 \\
\hline Blues & 2.00 & 2.00 & 2.00 \\
\hline Other pop & 2.01 & 2.01 & 2.01 \\
\hline Adult pop & 2.04 & 2.04 & 2.04 \\
\hline Soul & 2.04 & 2.04 & 2.04 \\
\hline Musicals & 2.16 & 2.16 & 2.16 \\
\hline Jazz & 2.18 & 2.18 & 2.18 \\
\hline Country \& western & & 2.25 & 2.25 \\
\hline Sixties pop & & 2.31 & 2.31 \\
\hline Classical & & 2.37 & 2.37 \\
\hline Opera & & & 2.53 \\
\hline Sogent & & & \\
\hline
\end{tabular}

Table 13 - Homogenous sub-sets of means of total recycling scores 


\begin{tabular}{|c|c|c|c|c|c|c|c|c|c|c|c|}
\hline & Tax & & & & Energy & & & & & Scotland & \\
\hline Musical & Set & Set & Set & & Set & Set & Set & Set & & Set & Set \\
\hline preference & 1 & 2 & 3 & & 1 & 2 & 3 & 4 & & 1 & 2 \\
\hline $\mathrm{R} \& \mathrm{~B}$ & 4.64 & & & $\begin{array}{l}\text { Hip } \\
\text { hop/rap }\end{array}$ & 5.48 & & & & Musicals & 5.62 & \\
\hline $\begin{array}{l}\text { Hip hop / } \\
\text { rap }\end{array}$ & 4.68 & & & $R \& B$ & 5.72 & 5.72 & & & $\begin{array}{l}\text { Sixties } \\
\text { pop }\end{array}$ & 5.79 & 5.79 \\
\hline $\begin{array}{l}\text { Current } \\
\text { chart pop }\end{array}$ & 4.85 & 4.85 & & $\begin{array}{l}\text { Current } \\
\text { chart } \\
\text { pop }\end{array}$ & 5.78 & 5.78 & 5.78 & & Opera & 5.92 & 5.92 \\
\hline DJ-based & 4.85 & 4.85 & & $\begin{array}{l}\text { Other } \\
\text { pop }\end{array}$ & 5.95 & 5.95 & 5.95 & 5.95 & Jazz & 6.00 & 6.00 \\
\hline $\begin{array}{l}\text { Dance / } \\
\text { house }\end{array}$ & 5.03 & 5.03 & 5.03 & DJ based & 6.20 & 6.20 & 6.20 & 6.20 & $\begin{array}{l}\text { Adult } \\
\text { pop }\end{array}$ & 6.14 & 6.14 \\
\hline Disco & 5.19 & 5.19 & 5.19 & $\begin{array}{l}\text { Dance / } \\
\text { house }\end{array}$ & 6.32 & 6.32 & 6.32 & 6.32 & Rock & 6.14 & 6.14 \\
\hline Other pop & 5.28 & 5.28 & 5.28 & $\begin{array}{l}\text { Adult } \\
\text { pop }\end{array}$ & 6.33 & 6.33 & 6.33 & 6.33 & Soul & 6.16 & 6.16 \\
\hline $\begin{array}{l}\text { Country } \\
\& \text { western }\end{array}$ & 5.31 & 5.31 & 5.31 & Disco & 6.33 & 6.33 & 6.33 & 6.33 & Disco & 6.20 & 6.20 \\
\hline Musicals & 5.41 & 5.41 & 5.41 & Musicals & 6.35 & 6.35 & 6.35 & 6.35 & Other & 6.28 & 6.28 \\
\hline Soul & 5.53 & 5.53 & 5.53 & Rock & 6.39 & 6.39 & 6.39 & 6.39 & Classical & 6.33 & 6.33 \\
\hline 1960s pop & 5.73 & 5.73 & 5.73 & Other & 6.42 & 6.42 & 6.42 & 6.42 & $\begin{array}{l}\text { Hip } \\
\text { hop/rap }\end{array}$ & 6.38 & 6.38 \\
\hline Rock & 5.86 & 5.86 & 5.86 & Soul & 6.51 & 6.51 & 6.51 & 6.51 & $\begin{array}{l}\text { Current } \\
\text { chart } \\
\text { pop }\end{array}$ & 6.44 & 6.44 \\
\hline Other & 5.90 & 5.90 & 5.90 & $\begin{array}{l}\text { Sixties } \\
\text { pop }\end{array}$ & 6.67 & 6.67 & 6.67 & 6.67 & $\begin{array}{l}\text { Other } \\
\text { pop }\end{array}$ & 6.44 & 6.44 \\
\hline Adult pop & 5.91 & 5.91 & 5.91 & $\begin{array}{l}\text { Country } \\
\& \\
\text { western }\end{array}$ & 6.71 & 6.71 & 6.71 & 6.71 & $\begin{array}{l}\text { Country } \\
\& \\
\text { western }\end{array}$ & 6.48 & 6.48 \\
\hline Indie & 6.02 & 6.02 & 6.02 & Opera & & 6.82 & 6.82 & 6.82 & $\begin{array}{l}\text { Dance / } \\
\text { house }\end{array}$ & 6.79 & 6.79 \\
\hline Jazz & 6.03 & 6.03 & 6.03 & Blues & & 6.95 & 6.95 & 6.95 & DJ based & 6.97 & 6.97 \\
\hline Blues & 6.05 & 6.05 & 6.05 & Classical & & & 7.05 & 7.05 & Indie & 7.05 & 7.05 \\
\hline Classical & & 6.29 & 6.29 & Indie & & & & 7.08 & $R \& B$ & 7.09 & 7.09 \\
\hline Opera & & & 6.37 & Jazz & & & & 7.21 & Blues & & 7.47 \\
\hline
\end{tabular}

Table 14 - Homogenous sub-sets of means of whether taxation should be raised to pay for improved public services; whether the Government should do more to exploit alternative energy sources; and whether Scotland should be granted full independence if desired by the population 


\begin{tabular}{|c|c|c|c|c|c|c|c|c|c|c|c|}
\hline & Euro & & Nuclear & & Green & & Health & & & & \\
\hline $\begin{array}{l}\text { Musical } \\
\text { preference }\end{array}$ & $\begin{array}{c}\text { Set } \\
1\end{array}$ & & $\begin{array}{c}\text { Set } \\
1\end{array}$ & & $\begin{array}{c}\text { Set } \\
1\end{array}$ & & $\begin{array}{c}\text { Set } \\
1\end{array}$ & $\begin{array}{c}\text { Set } \\
2\end{array}$ & $\begin{array}{c}\text { Set } \\
3\end{array}$ & $\begin{array}{c}\text { Set } \\
4\end{array}$ & $\begin{array}{c}\text { Set } \\
5\end{array}$ \\
\hline Musicals & 3.87 & Other & 4.16 & $\begin{array}{l}\text { Other } \\
\text { pop }\end{array}$ & 6.06 & $\begin{array}{l}\text { Hip } \\
\text { hop/rap }\end{array}$ & 7.06 & & & & \\
\hline $\begin{array}{l}\text { Current } \\
\text { chart pop }\end{array}$ & 3.91 & $\begin{array}{l}\text { Dance / } \\
\text { house }\end{array}$ & 4.20 & $\begin{array}{l}\text { Hip } \\
\text { hop/rap }\end{array}$ & 6.10 & $\begin{array}{l}\text { Dance / } \\
\text { house }\end{array}$ & 7.30 & 7.30 & & & \\
\hline $\begin{array}{l}\text { Country \& } \\
\text { western }\end{array}$ & 3.98 & $\begin{array}{l}\text { Other } \\
\text { pop }\end{array}$ & 4.34 & $\mathrm{R} \& \mathrm{~B}$ & 6.21 & $R \& B$ & 7.38 & 7.38 & 7.38 & & \\
\hline Adult pop & 4.14 & $R \& B$ & 4.36 & DJ based & 6.29 & DJ based & 7.49 & 7.49 & 7.49 & 7.49 & \\
\hline Disco & 4.15 & $\begin{array}{l}\text { Current } \\
\text { chart pop }\end{array}$ & 4.37 & $\begin{array}{l}\text { Dance / } \\
\text { house }\end{array}$ & 6.40 & Disco & 8.12 & 8.12 & 8.12 & 8.12 & 8.12 \\
\hline Rock & 4.18 & $\begin{array}{l}\text { Hip } \\
\text { hop/rap }\end{array}$ & 4.48 & Other & 6.41 & $\begin{array}{l}\text { Adult } \\
\text { pop }\end{array}$ & 8.15 & 8.15 & 8.15 & 8.15 & 8.15 \\
\hline $\begin{array}{l}\text { Sixties } \\
\text { pop }\end{array}$ & 4.25 & Disco & 4.52 & $\begin{array}{l}\text { Current } \\
\text { chart pop }\end{array}$ & 6.58 & Rock & 8.18 & 8.18 & 8.18 & 8.18 & 8.18 \\
\hline Other & 4.30 & Opera & 4.55 & Musicals & 6.63 & $\begin{array}{l}\text { Other } \\
\text { pop }\end{array}$ & 8.24 & 8.24 & 8.24 & 8.24 & 8.24 \\
\hline Classical & 4.32 & DJ based & 4.65 & Opera & 6.72 & $\begin{array}{l}\text { Current } \\
\text { chart pop }\end{array}$ & 8.25 & 8.25 & 8.25 & 8.25 & 8.25 \\
\hline$R \& B$ & 4.34 & Jazz & 5.06 & Jazz & 6.72 & Jazz & & 8.34 & 8.34 & 8.34 & 8.34 \\
\hline Other pop & 4.36 & $\begin{array}{l}\text { Adult } \\
\text { pop }\end{array}$ & 5.07 & Blues & 6.75 & Opera & & 8.37 & 8.37 & 8.37 & 8.37 \\
\hline $\begin{array}{l}\text { DJ based } \\
\text { Opera }\end{array}$ & $\begin{array}{l}4.54 \\
4.71\end{array}$ & $\begin{array}{l}\text { Soul } \\
\text { Rock }\end{array}$ & $\begin{array}{l}5.15 \\
5.20\end{array}$ & $\begin{array}{l}\text { Disco } \\
\text { Soul }\end{array}$ & $\begin{array}{l}6.83 \\
6.87\end{array}$ & $\begin{array}{l}\text { Other } \\
\text { Soul }\end{array}$ & & $\begin{array}{l}8.42 \\
8.43\end{array}$ & $\begin{array}{l}8.42 \\
8.43\end{array}$ & $\begin{array}{l}8.42 \\
8.43\end{array}$ & $\begin{array}{l}8.42 \\
8.43\end{array}$ \\
\hline Blues & 4.73 & Indie & 5.20 & $\begin{array}{l}\text { Adult } \\
\text { pop }\end{array}$ & 6.90 & Indie & & 8.47 & 8.47 & 8.47 & 8.47 \\
\hline $\begin{array}{l}\text { Dance / } \\
\text { house }\end{array}$ & 4.81 & Classical & 5.29 & Classical & 6.91 & $\begin{array}{l}\text { Sixties } \\
\text { pop }\end{array}$ & & 8.49 & 8.49 & 8.49 & 8.49 \\
\hline Jazz & 4.85 & $\begin{array}{l}\text { Musicals } \\
\text { Country }\end{array}$ & 5.34 & Rock & 6.93 & Blues & & & 8.61 & 8.61 & 8.61 \\
\hline Soul & 4.89 & $\begin{array}{l}\& \\
\text { western }\end{array}$ & 5.44 & $\begin{array}{l}\text { Sixties } \\
\text { pop }\end{array}$ & 6.93 & Classical & & & & 8.64 & 8.64 \\
\hline $\begin{array}{l}\text { Hip } \\
\text { hop/rap }\end{array}$ & 4.90 & $\begin{array}{l}\text { Sixties } \\
\text { pop }\end{array}$ & 5.49 & $\begin{array}{l}\text { Country } \\
\& \\
\text { western }\end{array}$ & 7.20 & Musicals & & & & 8.70 & 8.70 \\
\hline Indie & 5.43 & Blues & 5.55 & Indie & 7.33 & $\begin{array}{l}\text { Country } \\
\& \\
\text { western }\end{array}$ & & & & & 8.96 \\
\hline
\end{tabular}

Table 15 - Homogenous sub-sets of means of whether the UK should join the Euro if the economic conditions were favourable; whether nuclear weapons discourage international conflict; whether the Government should pay more attention to environmental / green issues; and whether Britain should retain state-funded health care 


\begin{tabular}{|c|c|c|c|c|}
\hline & Do not drive & $\begin{array}{c}\text { Received driving } \\
\text { penalty }\end{array}$ & Has been arrested & $\begin{array}{c}\text { Committed 'arrestable' } \\
\text { act }\end{array}$ \\
\hline Opera & $\begin{array}{c}8 \\
(13.6 \%) \\
\end{array}$ & $\begin{array}{c}27 \\
(45.8 \%) \\
\end{array}$ & $\begin{array}{c}5 \\
(8.5 \%) \\
\end{array}$ & $\begin{array}{c}12 \\
(20.3 \%) \\
\end{array}$ \\
\hline $\begin{array}{c}\text { Country \& } \\
\text { western }\end{array}$ & $\begin{array}{c}13 \\
(19.1 \%) \\
\end{array}$ & $\begin{array}{c}31 \\
(45.6 \%) \\
\end{array}$ & $\begin{array}{c}8 \\
(11.6 \%) \\
\end{array}$ & $\begin{array}{c}18 \\
(26.5 \%) \\
\end{array}$ \\
\hline Jazz & $\begin{array}{c}10 \\
(14.3 \%)\end{array}$ & $\begin{array}{c}26 \\
(37.1 \%)\end{array}$ & $\begin{array}{c}7 \\
(10.1 \%)\end{array}$ & $\begin{array}{c}27 \\
(38.6 \%)\end{array}$ \\
\hline Rock & $\begin{array}{c}33 \\
(17.4 \%) \\
\end{array}$ & $\begin{array}{c}68 \\
(35.8 \%) \\
\end{array}$ & $\begin{array}{c}13 \\
(6.8 \%) \\
\end{array}$ & $\begin{array}{c}62 \\
(32.6 \%) \\
\end{array}$ \\
\hline $\begin{array}{l}\text { Current chart } \\
\text { pop }\end{array}$ & $\begin{array}{c}21 \\
(16.5 \%) \\
\end{array}$ & $\begin{array}{c}36 \\
(28.3 \%) \\
\end{array}$ & $\begin{array}{c}2 \\
(1.6 \%) \\
\end{array}$ & $\begin{array}{c}36 \\
(28.3 \%) \\
\end{array}$ \\
\hline $\mathrm{R} \& \mathrm{~B}$ & $\begin{array}{c}26 \\
(21.0 \%)\end{array}$ & $\begin{array}{c}45 \\
(36.3 \%)\end{array}$ & $\begin{array}{c}11 \\
(8.7 \%)\end{array}$ & $\begin{array}{c}49 \\
(39.5 \%)\end{array}$ \\
\hline Soul & $\begin{array}{c}13 \\
(12.7 \%)\end{array}$ & $\begin{array}{c}45 \\
(44.1 \%)\end{array}$ & $\begin{array}{c}8 \\
(7.8 \%)\end{array}$ & $\begin{array}{c}38 \\
(36.9 \%)\end{array}$ \\
\hline Classical & $\begin{array}{c}22 \\
(15.6 \%)\end{array}$ & $\begin{array}{c}64 \\
(45.4 \%)\end{array}$ & $\begin{array}{c}8 \\
(5.6 \%) \\
\end{array}$ & $\begin{array}{c}35 \\
(25.2 \%)\end{array}$ \\
\hline Disco & $\begin{array}{c}20 \\
(13.8 \%) \\
\end{array}$ & $\begin{array}{c}61 \\
(42.1 \%) \\
\end{array}$ & $\begin{array}{c}6 \\
(4.1 \%) \\
\end{array}$ & $\begin{array}{c}37 \\
(25.2 \%) \\
\end{array}$ \\
\hline Dance / house & $\begin{array}{c}18 \\
(14.9 \%) \\
\end{array}$ & $\begin{array}{c}47 \\
(38.8 \%) \\
\end{array}$ & $\begin{array}{c}12 \\
(9.8 \%) \\
\end{array}$ & $\begin{array}{c}70 \\
(56.9 \%) \\
\end{array}$ \\
\hline Hip hop / rap & $\begin{array}{c}20 \\
(32.8 \%)\end{array}$ & $\begin{array}{c}21 \\
(34.4 \%)\end{array}$ & $\begin{array}{c}9 \\
(14.1 \%)\end{array}$ & $\begin{array}{c}34 \\
(53.1 \%)\end{array}$ \\
\hline Musicals & $\begin{array}{c}25 \\
(21.2 \%)\end{array}$ & $\begin{array}{c}27 \\
(22.9 \%)\end{array}$ & $\begin{array}{c}4 \\
(3.4 \%) \\
\end{array}$ & $\begin{array}{c}21 \\
(17.9 \%)\end{array}$ \\
\hline Blues & $\begin{array}{c}3 \\
(4.6 \%)\end{array}$ & $\begin{array}{c}32 \\
(49.2 \%)\end{array}$ & $\begin{array}{c}9 \\
(14.1 \%)\end{array}$ & $\begin{array}{c}21 \\
(33.3 \%)\end{array}$ \\
\hline Sixties pop & $\begin{array}{c}23 \\
(20.2 \%) \\
\end{array}$ & $\begin{array}{c}45 \\
(39.5 \%) \\
\end{array}$ & $\begin{array}{c}10 \\
(8.8 \%) \\
\end{array}$ & $\begin{array}{c}33 \\
(29.7 \%) \\
\end{array}$ \\
\hline Indie & $\begin{array}{c}19 \\
(15.3 \%)\end{array}$ & $\begin{array}{c}46 \\
(37.1 \%)\end{array}$ & $\begin{array}{c}7 \\
(5.6 \%)\end{array}$ & $\begin{array}{c}68 \\
(54.8 \%)\end{array}$ \\
\hline Adult pop & $\begin{array}{c}11 \\
(7.3 \%)\end{array}$ & $\begin{array}{c}66 \\
(43.7 \%)\end{array}$ & $\begin{array}{c}10 \\
(6.5 \%)\end{array}$ & $\begin{array}{c}42 \\
(27.6 \%)\end{array}$ \\
\hline DJ based & $\begin{array}{c}15 \\
(25.4 \%)\end{array}$ & $\begin{array}{c}19 \\
(32.2 \%)\end{array}$ & $\begin{array}{c}7 \\
(11.7 \%)\end{array}$ & $\begin{array}{c}39 \\
(67.2 \%)\end{array}$ \\
\hline Other pop & $\begin{array}{c}10 \\
(13.7 \%)\end{array}$ & $\begin{array}{c}31 \\
(42.5 \%)\end{array}$ & $\begin{array}{c}3 \\
(4.1 \%)\end{array}$ & $\begin{array}{c}23 \\
(31.9 \%)\end{array}$ \\
\hline \multirow[t]{2}{*}{ Other } & $\begin{array}{c}18 \\
(28.6 \%)\end{array}$ & $\begin{array}{c}18 \\
(28.6 \%)\end{array}$ & $\begin{array}{c}8 \\
(12.7 \%)\end{array}$ & $\begin{array}{c}29 \\
(46.8 \%)\end{array}$ \\
\hline & $\begin{array}{c}\chi^{2}(36)=73.47, \mathrm{p}< \\
0.001\end{array}$ & & $\begin{array}{c}\chi^{2}(18)=31.00, \mathrm{p}< \\
0.05\end{array}$ & $\begin{array}{c}\chi^{2}(18)=131.40, \mathrm{p}< \\
0.001\end{array}$ \\
\hline
\end{tabular}

Table 16 - Musical preference by whether the participant has ever received a minor motoring penalty; whether the participant has ever been arrested; and whether the participant has ever committed an act that would have led to arrest, had it been detected 
Set 1 Set 2 Set 3 Set 4 Set 5 Set 6

\begin{tabular}{|l|r|r|r|r|r|r|}
\hline Musicals & .13 & & & & & \\
\hline Adult pop & .16 & .16 & & & & \\
\hline Rock & .20 & .20 & & & & \\
\hline Classical & .23 & .23 & .23 & & & \\
\hline Current chart pop & .27 & .27 & .27 & & & \\
\hline Sixties pop & .27 & .27 & .27 & & & \\
\hline Disco & .32 & .32 & .32 & .32 & & \\
\hline Other pop & .36 & .36 & .36 & .36 & & \\
\hline Country \& western & .39 & .39 & .39 & .39 & .39 & \\
\hline Blues & .45 & .45 & .45 & .45 & .45 & \\
\hline Opera & .52 & .52 & .52 & .5 & .52 & \\
\hline Jazz & .63 & .63 & .63 & .63 & .62 & \\
\hline R\&B & .67 & .67 & .67 & .67 & .67 & \\
\hline Soul & & .81 & .81 & .81 & .81 & .81 \\
\hline Indie & & & .87 & .87 & .87 & .87 \\
\hline Other & & & & .94 & .94 & .94 \\
\hline Dance / house & & & & 1.05 & 1.05 \\
\hline Hip hop / rap & & & & & 1.41 \\
\hline DJ based & & & & & \\
\hline
\end{tabular}

Table 17 - Homogenous sub-sets of means of total drug use scores 


\begin{tabular}{|c|c|c|c|c|c|c|}
\hline & Solvents & Temazepam & Psilocybin & Amphetamine & LSD & Ecstacy \\
\hline Opera & $\begin{array}{c}1 \\
(1.8 \%)\end{array}$ & $\begin{array}{c}1 \\
(1.8 \%)\end{array}$ & $\begin{array}{c}1 \\
(1.8 \%)\end{array}$ & $\begin{array}{c}5 \\
(8.8 \%)\end{array}$ & $\begin{array}{c}4 \\
(7.1 \%)\end{array}$ & $\begin{array}{c}3 \\
(5.3 \%)\end{array}$ \\
\hline $\begin{array}{c}\text { Country \& } \\
\text { western }\end{array}$ & $\begin{array}{c}0 \\
(0 \%) \\
\end{array}$ & $\begin{array}{c}3 \\
(4.3 \%) \\
\end{array}$ & $\begin{array}{c}1 \\
(1.4 \%) \\
\end{array}$ & $\begin{array}{c}7 \\
(10.1 \%) \\
\end{array}$ & $\begin{array}{c}2 \\
(2.9 \%) \\
\end{array}$ & $\begin{array}{c}2 \\
(2.9 \%) \\
\end{array}$ \\
\hline Jazz & $\begin{array}{c}4 \\
(5.8 \%)\end{array}$ & $\begin{array}{c}1 \\
(1.4 \%)\end{array}$ & $\begin{array}{c}0 \\
(0 \%)\end{array}$ & $\begin{array}{c}7 \\
(10.1 \%)\end{array}$ & $\begin{array}{c}7 \\
(10.1 \%)\end{array}$ & $\begin{array}{c}4 \\
(6.0 \%) \\
\end{array}$ \\
\hline Rock & $\begin{array}{c}5 \\
(2.7 \%) \\
\end{array}$ & $\begin{array}{c}1 \\
(0.5 \%)\end{array}$ & $\begin{array}{c}1 \\
(0.5 \%)\end{array}$ & $\begin{array}{c}6 \\
(3.3 \%) \\
\end{array}$ & $\begin{array}{c}5 \\
(2.7 \%)\end{array}$ & $\begin{array}{c}7 \\
(3.8 \%) \\
\end{array}$ \\
\hline $\begin{array}{c}\text { Current chart } \\
\text { pop }\end{array}$ & $\begin{array}{c}1 \\
(0.8 \%)\end{array}$ & $\begin{array}{c}3 \\
(2.3 \%) \\
\end{array}$ & $\begin{array}{c}1 \\
(0.8 \%)\end{array}$ & $\begin{array}{c}8 \\
(6.2 \%) \\
\end{array}$ & $\begin{array}{c}4 \\
(3.1 \%) \\
\end{array}$ & $\begin{array}{c}6 \\
(4.7 \%) \\
\end{array}$ \\
\hline$R \& B$ & $\begin{array}{c}7 \\
(5.6 \%) \\
\end{array}$ & $\begin{array}{c}6 \\
(4.7 \%) \\
\end{array}$ & $\begin{array}{c}0 \\
(0 \%) \\
\end{array}$ & $\begin{array}{c}14 \\
(11.0 \%) \\
\end{array}$ & $\begin{array}{c}9 \\
(7.1 \%) \\
\end{array}$ & $\begin{array}{c}19 \\
(15.0 \%) \\
\end{array}$ \\
\hline Soul & $\begin{array}{c}6 \\
(5.9 \%) \\
\end{array}$ & $\begin{array}{c}3 \\
(3.0 \%)\end{array}$ & $\begin{array}{c}1 \\
(1.0 \%)\end{array}$ & $\begin{array}{c}15 \\
(14.9 \%)\end{array}$ & $\begin{array}{c}10 \\
(9.9 \%)\end{array}$ & $\begin{array}{c}11 \\
(11.1 \%) \\
\end{array}$ \\
\hline Classical & $\begin{array}{c}0 \\
(0 \%)\end{array}$ & $\begin{array}{c}1 \\
(0.7 \%)\end{array}$ & $\begin{array}{c}0 \\
(0 \%) \\
\end{array}$ & $\begin{array}{c}6 \\
(4.4 \%) \\
\end{array}$ & $\begin{array}{c}5 \\
(3.6 \%) \\
\end{array}$ & $\begin{array}{c}6 \\
(4.4 \%) \\
\end{array}$ \\
\hline Disco & $\begin{array}{c}4 \\
(2.8 \%) \\
\end{array}$ & $\begin{array}{c}4 \\
(2.8 \%) \\
\end{array}$ & $\begin{array}{c}1 \\
(0.7 \%) \\
\end{array}$ & $\begin{array}{c}13 \\
(9.1 \%) \\
\end{array}$ & $\begin{array}{c}3 \\
(2.1 \%) \\
\end{array}$ & $\begin{array}{c}6 \\
(4.2 \%) \\
\end{array}$ \\
\hline Dance / house & $\begin{array}{c}4 \\
(3.1 \%)\end{array}$ & $\begin{array}{c}7 \\
(5.4 \%) \\
\end{array}$ & $\begin{array}{c}6 \\
(9.1 \%) \\
\end{array}$ & $\begin{array}{c}25 \\
(19.4 \%)\end{array}$ & $\begin{array}{c}19 \\
(14.7 \%)\end{array}$ & $\begin{array}{c}27 \\
(20.9 \%) \\
\end{array}$ \\
\hline Hip hop / rap & $\begin{array}{c}8 \\
(12.5 \%) \\
\end{array}$ & $\begin{array}{c}6 \\
(9.2 \%) \\
\end{array}$ & $\begin{array}{c}1 \\
(1.5 \%) \\
\end{array}$ & $\begin{array}{c}11 \\
(16.9 \%) \\
\end{array}$ & $\begin{array}{c}10 \\
(15.4 \%) \\
\end{array}$ & $\begin{array}{c}12 \\
(18.5 \%) \\
\end{array}$ \\
\hline Musicals & $\begin{array}{c}1 \\
(0.9 \%)\end{array}$ & $\begin{array}{c}1 \\
(0.9 \%)\end{array}$ & $\begin{array}{c}0 \\
(0 \%)\end{array}$ & $\begin{array}{c}3 \\
(2.8 \%) \\
\end{array}$ & $\begin{array}{c}0 \\
(0 \%)\end{array}$ & $\begin{array}{c}3 \\
(2.7 \%) \\
\end{array}$ \\
\hline Blues & $\begin{array}{c}1 \\
(1.6 \%) \\
\end{array}$ & $\begin{array}{c}1 \\
(1.6 \%) \\
\end{array}$ & $\begin{array}{c}2 \\
(3.3 \%) \\
\end{array}$ & $\begin{array}{c}5 \\
(8.1 \%) \\
\end{array}$ & $\begin{array}{c}5 \\
(8.1 \%) \\
\end{array}$ & $\begin{array}{c}2 \\
(3.2 \%) \\
\end{array}$ \\
\hline Sixties pop & $\begin{array}{c}0 \\
(0 \%) \\
\end{array}$ & $\begin{array}{c}1 \\
(0.9 \%) \\
\end{array}$ & $\begin{array}{c}0 \\
(0 \%) \\
\end{array}$ & $\begin{array}{c}10 \\
(8.9 \%) \\
\end{array}$ & $\begin{array}{c}5 \\
(4.5 \%) \\
\end{array}$ & $\begin{array}{c}3 \\
(2.7 \%) \\
\end{array}$ \\
\hline Indie & $\begin{array}{c}7 \\
(5.7 \%)\end{array}$ & $\begin{array}{c}2 \\
(1.6 \%)\end{array}$ & $\begin{array}{c}1 \\
(0.8 \%)\end{array}$ & $\begin{array}{c}22 \\
(17.9 \%)\end{array}$ & $\begin{array}{c}11 \\
(8.9 \%)\end{array}$ & $\begin{array}{c}19 \\
(15.4 \%) \\
\end{array}$ \\
\hline Adult pop & $\begin{array}{c}1 \\
(0.7 \%)\end{array}$ & $\begin{array}{c}3 \\
(2.0 \%) \\
\end{array}$ & $\begin{array}{c}1 \\
(0.7 \%) \\
\end{array}$ & $\begin{array}{c}5 \\
(3.3 \%) \\
\end{array}$ & $\begin{array}{c}3 \\
(2.0 \%) \\
\end{array}$ & $\begin{array}{c}5 \\
(3.3 \%) \\
\end{array}$ \\
\hline DJ based & $\begin{array}{c}4 \\
(6.3 \%)\end{array}$ & $\begin{array}{c}4 \\
(6.3 \%) \\
\end{array}$ & $\begin{array}{c}5 \\
(7.9 \%)\end{array}$ & $\begin{array}{c}18 \\
(29.0 \%) \\
\end{array}$ & $\begin{array}{c}11 \\
(17.5 \%)\end{array}$ & $\begin{array}{c}20 \\
(31.7 \%)\end{array}$ \\
\hline Other pop & $\begin{array}{c}0 \\
(0 \%) \\
\end{array}$ & $\begin{array}{c}3 \\
(3.9 \%) \\
\end{array}$ & $\begin{array}{c}0 \\
(0 \%) \\
\end{array}$ & $\begin{array}{c}8 \\
(10.5 \%) \\
\end{array}$ & $\begin{array}{c}3 \\
(3.9 \%) \\
\end{array}$ & $\begin{array}{c}5 \\
(6.6 \%) \\
\end{array}$ \\
\hline \multirow[t]{2}{*}{ Other } & $\begin{array}{c}6 \\
(9.5 \%) \\
\end{array}$ & $\begin{array}{c}6 \\
(9.5 \%) \\
\end{array}$ & $\begin{array}{c}2 \\
(3.2 \%) \\
\end{array}$ & $\begin{array}{c}11 \\
(17.5 \%) \\
\end{array}$ & $\begin{array}{c}7 \\
(11.1 \%) \\
\end{array}$ & $\begin{array}{c}8 \\
(12.7 \%) \\
\end{array}$ \\
\hline & Cocaine & Heroin & $\begin{array}{c}\text { Magic } \\
\text { mushrooms }\end{array}$ & Cannabis & $\begin{array}{c}\text { Never } \\
\text { tried }\end{array}$ & \\
\hline Opera & $\begin{array}{c}3 \\
(5.3 \%)\end{array}$ & $\begin{array}{c}0 \\
(0 \%)\end{array}$ & $\begin{array}{c}7 \\
(12.3 \%)\end{array}$ & $\begin{array}{c}14 \\
(24.6 \%)\end{array}$ & $\begin{array}{c}40 \\
(71.4 \%)\end{array}$ & \\
\hline $\begin{array}{c}\text { Country \& } \\
\text { western }\end{array}$ & $\begin{array}{c}4 \\
(5.8 \%) \\
\end{array}$ & $\begin{array}{c}2 \\
(2.9 \%) \\
\end{array}$ & $\begin{array}{c}4 \\
(5.8 \%) \\
\end{array}$ & $\begin{array}{c}16 \\
(23.2 \%) \\
\end{array}$ & $\begin{array}{c}47 \\
(68.1 \%) \\
\end{array}$ & \\
\hline Jazz & $\begin{array}{c}7 \\
(10.1 \%) \\
\end{array}$ & $\begin{array}{c}0 \\
(0 \%) \\
\end{array}$ & $\begin{array}{c}5 \\
(7.2 \%) \\
\end{array}$ & $\begin{array}{c}27 \\
(39.1 \%) \\
\end{array}$ & $\begin{array}{c}38 \\
(55.1 \%) \\
\end{array}$ & \\
\hline Rock & $\begin{array}{c}4 \\
(2.2 \%) \\
\end{array}$ & $\begin{array}{c}1 \\
(0.5 \%)\end{array}$ & $\begin{array}{c}9 \\
(4.9 \%) \\
\end{array}$ & $\begin{array}{c}63 \\
(34.2 \%) \\
\end{array}$ & $\begin{array}{c}112 \\
(61.2 \%)\end{array}$ & \\
\hline $\begin{array}{l}\text { Current chart } \\
\text { pop }\end{array}$ & $\begin{array}{c}7 \\
(5.5 \%) \\
\end{array}$ & $\begin{array}{c}2 \\
(1.6 \%)\end{array}$ & $\begin{array}{c}5 \\
(3.9 \%) \\
\end{array}$ & $\begin{array}{c}34 \\
(26.6 \%) \\
\end{array}$ & $\begin{array}{c}74 \\
(57.8 \%) \\
\end{array}$ & \\
\hline$R \& B$ & $\begin{array}{c}15 \\
(11.8 \%) \\
\end{array}$ & $\begin{array}{c}0 \\
(0 \%)\end{array}$ & $\begin{array}{c}8 \\
(6.3 \%) \\
\end{array}$ & $\begin{array}{c}52 \\
(40.9 \%)\end{array}$ & $\begin{array}{c}48 \\
(38.1 \%)\end{array}$ & \\
\hline Soul & $\begin{array}{c}13 \\
(12.9 \%) \\
\end{array}$ & $\begin{array}{c}2 \\
(2.0 \%) \\
\end{array}$ & $\begin{array}{c}13 \\
(12.9 \%) \\
\end{array}$ & $\begin{array}{c}42 \\
(41.6 \%) \\
\end{array}$ & $\begin{array}{c}51 \\
(50.5 \%) \\
\end{array}$ & \\
\hline Classical & $\begin{array}{c}4 \\
(2.9 \%) \\
\end{array}$ & $\begin{array}{c}2 \\
(1.5 \%) \\
\end{array}$ & $\begin{array}{c}3 \\
(2.2 \%) \\
\end{array}$ & $\begin{array}{c}37 \\
(27.0 \%) \\
\end{array}$ & $\begin{array}{c}92 \\
(67.2 \%) \\
\end{array}$ & \\
\hline
\end{tabular}




\begin{tabular}{|c|c|c|c|c|c|}
\hline Disco & $\begin{array}{c}4 \\
(2.8 \%)\end{array}$ & $\begin{array}{c}1 \\
(0.7 \%)\end{array}$ & $\begin{array}{c}12 \\
(8.4 \%)\end{array}$ & $\begin{array}{c}40 \\
(28.0 \%)\end{array}$ & $\begin{array}{c}93 \\
(65.0 \%) \\
\end{array}$ \\
\hline Dance / house & $\begin{array}{c}20 \\
(15.5 \%)\end{array}$ & $\begin{array}{c}3 \\
(2.3 \%)\end{array}$ & $\begin{array}{c}16 \\
(12.4 \%)\end{array}$ & $\begin{array}{c}62 \\
(48.1 \%) \\
\end{array}$ & $\begin{array}{c}48 \\
(37.5 \%)\end{array}$ \\
\hline Hip hop / rap & $\begin{array}{c}9 \\
(13.8 \%) \\
\end{array}$ & $\begin{array}{c}1 \\
(1.5 \%) \\
\end{array}$ & $\begin{array}{c}8 \\
(12.3 \%) \\
\end{array}$ & $\begin{array}{c}27 \\
(41.5 \%)\end{array}$ & $\begin{array}{c}18 \\
(28.1 \%)\end{array}$ \\
\hline Musicals & $\begin{array}{c}2 \\
(1.9 \%) \\
\end{array}$ & $\begin{array}{c}0 \\
(0 \%)\end{array}$ & $\begin{array}{c}1 \\
(0.9 \%)\end{array}$ & $\begin{array}{c}22 \\
(19.8 \%)\end{array}$ & $\begin{array}{c}85 \\
(76.6 \%) \\
\end{array}$ \\
\hline Blues & $\begin{array}{c}4 \\
(6.5 \%) \\
\end{array}$ & $\begin{array}{c}2 \\
(3.2 \%)\end{array}$ & $\begin{array}{c}3 \\
(4.8 \%)\end{array}$ & $\begin{array}{c}21 \\
(33.9 \%)\end{array}$ & $\begin{array}{c}41 \\
(66.1 \%)\end{array}$ \\
\hline Sixties pop & $\begin{array}{c}3 \\
(2.7 \%)\end{array}$ & $\begin{array}{c}1 \\
(0.9 \%)\end{array}$ & $\begin{array}{c}6 \\
(5.4 \%) \\
\end{array}$ & $\begin{array}{c}41 \\
(36.6 \%)\end{array}$ & $\begin{array}{c}67 \\
(59.8 \%)\end{array}$ \\
\hline Indie & $\begin{array}{c}8 \\
(6.5 \%) \\
\end{array}$ & $\begin{array}{c}2 \\
(1.6 \%) \\
\end{array}$ & $\begin{array}{c}12 \\
(9.8 \%)\end{array}$ & $\begin{array}{c}73 \\
(58.9 \%) \\
\end{array}$ & $\begin{array}{c}44 \\
(36.1 \%) \\
\end{array}$ \\
\hline Adult pop & $\begin{array}{c}6 \\
(4.0 \%)\end{array}$ & $\begin{array}{c}1 \\
(0.7 \%)\end{array}$ & $\begin{array}{c}4 \\
(2.7 \%)\end{array}$ & $\begin{array}{c}42 \\
(28.0 \%)\end{array}$ & $\begin{array}{c}101 \\
(67.3 \%)\end{array}$ \\
\hline DJ based & $\begin{array}{c}18 \\
(28.6 \%)\end{array}$ & $\begin{array}{c}4 \\
(6.3 \%)\end{array}$ & $\begin{array}{c}10 \\
(15.9 \%)\end{array}$ & $\begin{array}{c}40 \\
(63.5 \%)\end{array}$ & $\begin{array}{c}17 \\
(27.0 \%)\end{array}$ \\
\hline Other pop & $\begin{array}{c}3 \\
(3.9 \%)\end{array}$ & $\begin{array}{c}0 \\
(0 \%)\end{array}$ & $\begin{array}{c}2 \\
(2.6 \%)\end{array}$ & $\begin{array}{c}24 \\
(31.6 \%)\end{array}$ & $\begin{array}{c}47 \\
(61.8 \%)\end{array}$ \\
\hline Other & $\begin{array}{c}6 \\
(9.5 \%) \\
\end{array}$ & $\begin{array}{c}4 \\
(6.3 \%) \\
\end{array}$ & $\begin{array}{c}5 \\
(7.9 \%) \\
\end{array}$ & $\begin{array}{c}22 \\
(34.9 \%)\end{array}$ & $\begin{array}{c}36 \\
(57.1 \%) \\
\end{array}$ \\
\hline
\end{tabular}

Table 18 - Musical preference by whether participants have ever tried solvents; temazepam; psilocybin; amphetamine; LSD; ecstacy; cocaine, heroin, magic mushrooms, cannabis; and no drugs 